University of Warwick institutional repository

This paper is made available online in accordance with

publisher policies. Please scroll down to view the document

itself. Please refer to the repository record for this item and our

policy information available from the repository home page for further information.

To see the final version of this paper please visit the publisher's website. Access to the published version may require a subscription.

Authors: $\quad$ Livanos, I. \& Pouliakas, $\mathrm{K}$

Article title: Wage Returns to University Disciplines in Greece:

Are Greek Higher Education Degrees Trojan

Horses?

Year of $\quad$ Not yet published

publication:

Link to http://www.tandf.co.uk/journals/titles/09645292.asp

published

version:

Publisher None

statement: 


\title{
Wage Returns to University Disciplines in Greece: Are Greek Higher Education Degrees Trojan Horses?
}

\author{
Livanos, I. ${ }^{1} \&$ Pouliakas, $\mathrm{K}^{2}$
}

Key Words: academic disciplines, wage returns, higher education, Greece

JEL- Code: J24, J31, J38.

\begin{abstract}
This paper examines the wage returns to qualifications and academic disciplines in the Greek labour market. Exploring wage responsiveness across various degree subjects in Greece is interesting, as it is characterised by high levels of graduate unemployment, which vary considerably by field of study, and relatively low levels of wage flexibility. Using micro-data from recently available waves (2002-2003) of the Greek Labour Force Survey (LFS), the returns to academic disciplines are estimated by gender and public/private sector. Quantile regressions and cohort interactions are also used to capture the heterogeneity in wage returns across the various disciplines. The results show considerable variation in wage premiums across the fields of study, with lower returns for those that have a marginal role to play in an economy with a rising services/shrinking public sector. Educational reforms that pay closer attention to the future prospects of university disciplines are advocated.
\end{abstract}

\footnotetext{
${ }^{1}$ Research Fellow, Institute for Employment Research, University of Warwick, Coventry, UK, email: I.Livanos@warwick.ac.uk.

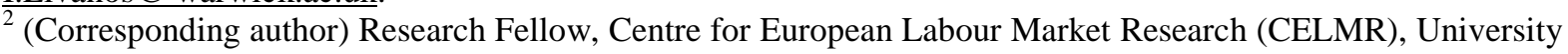
of Aberdeen Business School, Edward Wright Building, Dunbar Street, Old Aberdeen AB24 3QY, UK - Tel. ++44 01224 272172, email: k.pouliakas@abdn.ac.uk.
} 


\section{Introduction}

Following the predictions of the traditional theory of human capital (HC) (Becker, 1964; Ben-Porath, 1967; Mincer, 1974), much of the empirical work (e.g. Psacharopoulos, 1994) has largely focussed on estimating the rate of return to a homogeneous stock of HC measured by the years of schooling and/or levels of qualifications (e.g. PhD, Masters degree, tertiary education etc.). However, the standard HC model has been criticized for its inability to yield any predictions concerning the occupational distribution (Blaug, 1976), as the conventional practice of estimating HC earnings functions (HCEFs) conceals most of the diversity of education. Yet there are plenty of reasons why considering variations in types of HC may be as important as considering variations in levels. For example, interest continues to focus on the implications of the degree conferral process for graduate unemployment (Machin and McNally, 2007) or the under-representation of women/minorities in various degrees (Machin and Puhani, 2003; Livanos and Pouliakas, 2009). Thus, by examining closer the kinds of subjects which people choose to invest in, one can understand important phenomena regarding the wage distribution.

Exploring this issue within the Greek labour market context assumes greater importance due to the fact that Greece is recently embarking on a major reform of its higher education system. This entails, most significantly, calls for the relaxation of Article 16 of its constitution in which the provision of 'free' education for all Greek citizens is enshrined. Such a measure is expected to lead to the establishment of (non-profit) privately funded universities that will complement the existing state institutions. One of the main reasons underlying this initiative is the wide recognition that the degree conferral process is weakly liked to the labour market in Greece. Furthermore, with the introduction of privately funded universities, there is a theoretical case in favour of the differentiation of fees by subject of degree studied or by institution attended (Greenaway and Haynes, 2003). It is thus evident that for the sake of the efficient allocation of human resources, it is important to study the labour market implications of the degree selection process.

This paper contributes to the existing literature in several ways. First, it provides the most recent estimates of the returns to educational qualifications in Greece, based on unexplored data from the 
country's Labour Force Survey (LFS). Second, it is the first Greek study to assess the heterogeneities in wage returns to a university degree, specifically with respect to the chosen field of study of graduates. This is in general a relatively under-researched area in the international literature. Third, it examines the case of Greece which is interesting due to the pronounced disparities in graduate unemployment rates found across fields of study (Livanos, 2008[a]). Finally, the study adopts the method of quantile regression and examines different cohorts of the Greek labour force to investigate the systematic variation in the wage returns to different degrees, in an attempt to further explore the underlying demand and supply dynamics that have affected Greek graduates.

The structure of the paper is as follows. Section 2 provides a brief overview of the Greek education system, while section 3 describes the available literature on the returns to education in Greece and by field of study more broadly. Descriptive statistics of the subjects of degree studied and of the relative wages of Greek employees is then provided in Section 4, while the relevant econometric methodology is outlined in Section 5. The wage returns to various academic qualifications and disciplines are subsequently estimated in Section 6. Heterogeneities in the average returns to higher education are also explored. Finally, Section 7 discusses the implications of the findings for the design of appropriate educational policies within Greece, while Section 8 concludes.

\section{Higher Education in Greece}

The tertiary education system in Greece is divided into (i) University Education, which is provided by the Higher Educational Institutes (named AEI on the basis of the Greek acronyms), and (ii) Higher Technological Education, which is provided by the Technological Educational Institutes (TEI). ${ }^{1}$

During the last few decades Greece has experienced a rapid increase in its student population, stemming from (among other factors) the higher income levels of the population and EU accession that allowed relatively cheap enrolment to foreign universities (Psacharopoulos, 1990). Estimates reported in Tsakloglou and Cholezas (2005) suggest that the percentage of the labour force with tertiary education increased from $14.1 \%$ in 1988 to $22.2 \%$ in $1999 .{ }^{2}$ Moreover, while $15 \%$ of the respective cohort went into university-level programmes in 1995, by 2006 this had more than tripled to $49 \%$. 
Indicative of this sharper than average increase is that at an OECD level the share of secondary education graduates that entered tertiary education rose on average by a half (OECD, 2009). As noted by Psacharopoulos (2003), the problem lies in the fact that the direct costs of education are zero (since higher education is free in Greece), which has raised enrolment in general, and in specific disciplines in particular.

Indeed, a cause of greater concern, in the face of rising graduate figures, is the tendency of students to select university disciplines that are regarded as 'prestigious' or as acting as a passport for entry into the historically large, and superior in terms of overall working conditions, Greek public sector (Katsanevas, 2002; OECD, 2005). For instance, in the academic year 1999/2000 it was estimated that one in two students of higher education were registered in courses that are associated with the conventional fields of Law, Education, Social Science or Medicine. By contrast, only one in twenty students were registered in high-tech departments concerned with information technologies (Papamatthaioy, 2002). ${ }^{3}$

Furthermore, Patrinos (1997) has illustrated that the aforementioned excess supply of graduates has led to an overeducation rate of approximately $16 \%$ of the university educated labour force in Greece, which varies considerably across different disciplines. Dolton and Marcenaro-Gutierrez (2009) also show, using comparable ECHP data, that in the 1994-2001 period Greece had one of the highest overeducation rates amongst the EU countries examined. Thus, it would appear to be the case that a large part of the significant investment of Greeks in HC has been directed towards professions that are not necessarily linked to the needs of the labour market. ${ }^{4}$

Imbalances in the supply and demand of particular professions in Greece are expected to result mainly in higher joblessness or underemployment and not in lower wages. On the one hand, Livanos (2008[a]) found that the chances of unemployment vary significantly across the various fields of study, with graduates of disciplines that are traditionally related to the public sector (e.g. Humanities and Sociology) having poor employment prospects, in contrast to those associated with the changing needs of the private sector (e.g. Computer Science). On the other hand, the Greek labour market is in general characterised by wage rigidity, since sectoral and enterprise pay rates are usually dictated by minimum 
effective floors that are set by national general collective agreements. An interesting question, therefore, is to what extent the above-mentioned graduate supply patterns in Greece have affected the returns to various fields of study, or whether they have resulted solely in higher unemployment rates. ${ }^{5}$

\section{Literature Review}

\subsection{The returns to education in Greece}

Previous studies in the Greek literature have focussed on calculating the rate of return to years of schooling or to various academic qualifications without taking into consideration the variation in the fields of study. Indeed, while there exist a number of papers investigating the private returns to a university education in Greece (e.g. Cholezas and Tsakloglou, 1999; Magoula and Psacharopoulos, 1999; Kanellopoulos et al., 2003; Prodromidis and Prodromidis, 2007), it had not been possible in the past to differentiate between the types of education due to lack of appropriate information in most available datasets.

It is now well documented that the returns to tertiary education have diminished over the last few decades in Greece due to the large expansion of the educational sector. For instance, Labropoulos and Psacharopoulos (1992) and Kanellopoulos (1997) report falling marginal private returns to higher education in Greece between the 1960s and 1980s (e.g. the former show the returns of male private sector employees falling from $15.1 \%$ in 1975 to $10.2 \%$ in 1985). In addition, the studies of Magoula and Psacharopoulos (1999) and Cholezas and Tsakloglou (1999) illustrate that even though there has been a decline in wage premiums offered to tertiary education graduates in recent decades, they have been surprisingly resilient presumably in the face of a strong demand side of the market. For instance, Cholezas and Tsakloglou (1999, p. 8), estimate that over the period 1974-1994 the average rate of return fell from $9.3 \%$ in 1974 to $8.7 \%$ in 1994 for males and from $11.9 \%$ to $10.4 \%$ for females. The same authors, as part of an EU project (PURE), revise their estimates to 6.3\% for males and $8.6 \%$ for females in 1994. These returns are somewhat lower than those of the remaining EU-15 countries, which broadly ranged from $4 \%$ (Sweden) to 11\% (UK) (Harmon et al., 2001). 


\subsection{The returns to subject of degree}

Given the increasing interest in the non-linearity of the returns to education, there now exist a limited number of studies that have examined the field of qualification primarily in the US and UK. The studies of Grubb (1992) and Rumberger and Thomas (1993) in the US, Finnie and Frenette (2003) in Canada, and those of Blackaby et al. (1999), Blundell et al. (2000), Walker and Zhu (2001), O’Leary and Sloane (2005), Bratti et al. (2008) and Kelly et al. (2008) for the UK, all show substantial variation in the wage returns to different fields of study. In most cases it is shown that the rates of return to courses such as Law, Engineering, Social Sciences and Business are significantly higher than those of the Arts, Education and Humanities. Significant gender differences in the rates of return are also reported, with women tending to select the latter disciplines which offer lower lifetime earnings.

\section{Data and Descriptive Statistics}

The analysis draws on micro-data from the Greek LFS for the second quarter of the years 2002-2003. ${ }^{6}$ The Greek LFS is administered by the National Statistical Service of Greece (ESYE), in accordance with the definitions of the European LFS. Since 1998, it is being conducted four times per year in order to meet the standards set by Eurostat. The yearly sample of the survey consists of 30,000 households and includes approximately 80,000 observations.

Though five years of data (2000-2004) were made available to us by ESYE, two waves (20022003) have been retained for the analysis in this paper, since the variables required for the empirical specification (e.g. wages, tenure, hours of work) only existed in full in those waves. Thus, in the years 2002-2003 the employed in the sample amounted to 55,792 observations, of which 17,735 were selfemployed (32\%) and 33,532 were salaried employees (60\%). The remaining 4,525 (8\%) were classified as assistants of the family business. For the purposes of this study a sample of paid employees only, aged between 15-64 years old, is retained, that excludes those who have not yet completed their studies and those with non-Greek citizenship (since they may have not been educated within the Greek Higher Education system). This results in a total of 29,749 observations, of which 7,108 (24\%) are graduates of the Greek tertiary education system. 
Table 1 illustrates the distribution of the sample observations across the different educational qualifications and degrees, as well as the dispersion of net monthly graduate earnings. ${ }^{7}$ It is clear from the table that the mean wage of university graduates (€962) significantly exceeds that of the entire population of employees (€831). In addition, there are marked variations in the subject of degree from which graduates have matriculated, with Economics and Business (21\%), Humanities (14\%) and Education (13.6\%) occupying the lion's share. One can also observe a strikingly low proportion of graduates from Computing Science (0.7\%), which has raised concerns about the capability of Greece to keep pace with the rapid speed of the information technology era (Papamatthaioy, 2002). Differences in the average level of pay by field of study are also observed, with mean monthly earnings being highest for Medicine (€1230), followed by Polytechnic (€1097), Law (€1083) and Computing Science (€1052) degrees. A notable feature of the data is the lower average earnings of graduates from the TEIs (€887) compared to those from AEIs (€978).

\section{[INSERT TABLE 1 HERE]}

Table 2 also presents descriptive statistics of the most important variables that may contribute to the above discrepancy in pay amongst degree holders. Important phenomena that characterize the Greek labour market emerge, such as a substantial gender pay gap (Papapetrou, 2004; Cholezas and Tsakloglou, 2006; Livanos and Pouliakas, 2009). It is also worth mentioning some other notable features of the Greek economy, such as the higher average wages received by workers in the public relative to the private sector (Kanellopoulos, 1997; Papapetrou, 2006), a very low (high) proportion of part-time (temporary contract) employment (Pouliakas and Theodossiou, 2005), lower mean wages of recent cohorts (related to the increasing participation rate of female labour in recent decades) and a high percentage of workers employed in small and medium-sized enterprises (SMEs). One can also observe that the sample of university graduates consists of mostly female employees, who are mainly employed in permanent, full-time, public sector jobs.

[INSERT TABLE 2 HERE] 


\section{Econometric Methodology}

The empirical analysis of the paper employs a slight modification of the Mincer (1974) HCEF that estimates the impact of different degrees on graduate earnings, after controlling for a standard set of demographic characteristics. The Mincer-type earnings functions that are fitted are defined as follows:

$$
\ln W_{i j}=\sum_{j=1}^{J} S_{i j} \alpha_{j}+\mathbf{x}_{i}^{\prime} \boldsymbol{\beta}+\varepsilon_{i}
$$

where $W_{i j}$ are the monthly earnings of individual $i$ with educational attainment level $j(j=1, \ldots, J), S_{i j}$ are dummy variables taking the value 1 for each qualification or type of degree that individual $i$ has graduated from and 0 otherwise, $\boldsymbol{x}_{i}$ is a vector of personal characteristics which affect occupational earnings and $\varepsilon_{i}$ is a random error term. The coefficient $\alpha_{j}$ is subsequently the (log) wage return/ premium that graduating from degree $j$ imparts relative to the default case (usually secondary qualifications which would have permitted admission to tertiary education), while $\boldsymbol{\beta}$ is the vector of the marginal returns of the characteristics in $\boldsymbol{x}_{i}$.

Quantile regressions (QR) are also performed that seek to identify the wage premium offered to various degrees at different segments of the wage distribution. Such a technique allows the exploration of any potential heterogeneity in the returns to academic disciplines in the Greek labour market. As formalized by Buchinsky (1994), the linear quantile regression function

$$
Q_{\tau}\left(\ln W_{i} \mid x_{i}\right)=x_{i}^{\prime} \beta_{\tau}
$$

can be estimated by solving the optimization problem

$$
\hat{\beta}_{\tau}=\arg \min \beta \in \mathfrak{R}^{K} \sum_{i=1}^{N} \rho_{\tau}\left(\ln W_{i}-x_{i}^{\prime} \beta_{\tau}\right)
$$

where $\tau\{\tau \in(0,1)\}$ denotes the $\tau_{\text {th }}$ quantile of the wage distribution, $\rho_{\tau}$ is known as the piecewise linear "check function" and $\boldsymbol{x}_{i}$ is a vector of exogenous control variables. As is standard, the QR estimates 
found by solution to (3) indicate the marginal change in the $\tau_{\text {th }}$ quantile due to a marginal change in the $j$-th regressor $x_{i j}$.

It is well-known that the condition $E\left(\varepsilon_{i} \mid \mathbf{x}_{i}, S_{i j}\right)=0$ is required so that the OLS estimates of equation (1) are unbiased. Nonetheless, several econometric problems arise when inferring the wage returns to different degrees obtained by least squares. Prominent among these is the standard 'ability bias' that results due to the non-zero correlation between the unobserved earnings capacity of individuals and their educational attainment level, which confounds the causal relationship between education and wages (Card, 1999). Part of the return to particular academic disciplines may also reflect a positive quality (or selection) effect, or differences in stringency requirements, whereby idiosyncratic unobserved characteristics of the respondents may affect both their choice of degree subject and their wage growth. Such endogeneity problems are likely to lead to overestimation of the sole contribution of higher education degrees to labour productivity.

In order to tackle these issues, the literature has either utilized datasets that contain a wide set of socio-economic and family background controls that may proxy the unobserved earnings capacity of individuals (e.g. Blundell et al. 2000; Bratti et al. 2008), or has embarked on instrumental variables (IV) techniques (e.g. Card, 1999). Recently, O’Leary and Sloane (2005) used Leslie’s (2003) index of student quality based on pre-university entry test scores as an additional control in the regression. These authors find that the inclusion of the index has a notable yet not dramatic effect on the OLS estimates.

A further issue of empirical concern is that sample selection bias may affect the estimates of the wage returns when the researcher does not take into account the potential non-randomness of the chosen sample of paid employees. In particular, both the participation of individuals into paid employment and their decision to become salaried employees or self-employed is likely to be endogenously related to the type of university degree that they hold. Many authors have therefore examined the possibility that the wage returns found for female participants in the labour market are not representative of the 'true' average wage premium (Heckman, 1979). In addition, given the high rate of male self-employment in Greece that varies across academic disciplines, there is also a potential 
for selectivity bias in the returns of the male sub-sample. In order to correct the OLS estimates of equation (1) for such selectivity bias, maximum likelihood estimates of a two-equation system are therefore also reported in this paper, details of which are given in Appendix 1.

Buchinsky (1998) has nevertheless illustrated that the standard Heckman two-step procedure is not directly applicable to a quantile regression framework, as the source of the sample selection bias is of an unknown form. Instead, he proposes a procedure based on semi-parametric calculation of a single (linear) index selection equation and nonparametric estimation of the second step outcome function. ${ }^{8}$ However, data limitations have not allowed the implementation of such a sophisticated technique in this paper.

Due to the unavailability of a rich set of family background variables and ability-related proxies, it has often been argued that estimates from the LFS overestimate wage returns relative to cohort-based studies (Bratti et al., 2008). As noted by Heckman et al. (2006), cohort-based rather than crosssectional datasets should be used when the purpose is to estimate historical returns and make comparisons over time, since cohort changes are likely to be diluted in cross-section data.

To the author's knowledge, data containing information on graduate cohorts in Greece are unavailable, which makes the LFS the best possible source of knowledge on the contemporary wage and employment outcomes of Greek graduates. It is nonetheless believed that the estimates presented in this paper should paint a robust picture of the underlying heterogeneities in the wage returns in Greece, as every possible attempt is made (given constraints) to account for empirical complications. Specifically, the empirical analysis has corrected for potential sample selection bias that arises due to the omission of inactive and self-employed workers from the sample. Moreover, an attempt has been made to incorporate a proxy for unobserved ability in the regression, and to control for any confounding cohort effects. Finally, in order to ameliorate the effect of measurement error bias, the specific fields of study have been deliberately categorised into relatively broad groupings. Nevertheless, it is acknowledged that data constraints have inhibited the correction of bias arising from self-selection of individuals of differing abilities across alternative fields of study. The evidence 
regarding the response of wage returns to supply-side changes should also be interpreted with caution given the cross-sectional nature of the study.

\section{The Returns to Education in Greece}

\subsection{Returns to Educational Qualifications in Greece}

Table 3 shows estimates of Mincer earnings functions that are computed on the entire sample of the dataset and including educational qualifications (e.g. $\mathrm{PhD}$, Masters, tertiary degree etc.) as explanatory variables. In order to accurately capture the wage returns, a relatively robust set of control variables has been selected, namely age, tenure, marital status, region of residence, whether the job is full-time or part-time, weekly hours worked and a set of time and cohort fixed indicator variables. This follows the suggestion of Pereira and Martins (2004), and the empirical practice of past studies using the UK LFS (Walker and Zhu, 2001; Sloane and O’Leary, 2005), who argue that in order to obtain the full effect of education on earnings one should avoid the inclusion in the wage equation of covariates that reflect post-schooling decisions (such as the attributes of individuals' jobs, since these are correlated with the level of educational attainment and may be endogenous). Given this specification, separate analyses are thus conducted by gender, since the wage profiles of men and women are likely to differ in a significant manner.

The findings in Table 3 are in agreement with previous studies confirming the positive contribution of higher education to wages in Greece (Magoula and Psacharopoulos, 1999; Cholezas and Tsakloglou, 1999; Prodromidis and Prodromidis, 2007), as well as the fact that the private average returns to education are higher for women than for men (Papapetrou, 2004; Cholezas and Tsakloglou, 2006; Pouliakas and Livanos, 2009). For instance, an undergraduate university degree (AEI) is associated with an estimated coefficient of 0.22 for men and 0.26 for women relative to the omitted secondary level qualification (see Table A1 in the Appendix). ${ }^{9}$ These correspond to wage premia of $24 \%$ and $29 \%$, respectively, once the $e^{\alpha}-1$ conversion is used. The wage returns to a first degree are also found to be higher in the private rather than in the public sector. ${ }^{10}$ To the extent that market forces determine the shape of wage profiles in the private sector, this finding is an indication that the 
contribution of a university degree to individuals' wages is likely to be muted in state jobs, given that seniority wage profiles, administrative pay scales and powerful trade unions play a predominant role in the pay bargaining process of that sector in Greece (Papapetrou, 2006). Further evidence in this regard, observed in Table A1, is also evident by the fact that the returns to tenure are found to be higher in the public rather than in the private sector.

\section{[INSERT TABLE 3 HERE]}

The Greek labour market is also found to offer lower rewards to individuals holding degrees from TEIs, despite recent attempts by the government to elevate the status of such institutions so that they become equivalent to AEIs. This finding reflects the fact that entry requirements are generally lower in TEI Schools relative to AEIs, which results in the attraction of a lower ability pool of students. TEI courses are generally shorter than those of AEI's as well, and are widely regarded as being less effective in the task of raising the productivity of their graduates. These arguments may be extended to the low returns of graduates from IEK/Colleges, who are predominantly individuals that were unsuccessful in their attempt to gain university entry via the Pan-Hellenic national examinations.

Finally, marked returns to post-graduate qualifications (both Masters and $\mathrm{PhD}$ ) are found, though for PhD degree holders these returns are pronounced only in the public sector. ${ }^{11}$

\subsection{Robustness Checks to Estimates of Returns to Qualifications in Greece}

A number of tests have been performed to validate that the estimates of the wage returns in Greece described in section 6.1 are robust. For instance, estimation of the returns to various levels of educational attainment has been replicated on a sample of full-time permanent contract workers only (shown in Table A1), to examine the extent to which wage premia may be affected by the presence of precarious contracts in the labour market. Small differences in the magnitude of the coefficients are found, which is not surprising given the relatively small incidence of part-time employment in Greece.

Particular attention is paid to the presence of selectivity biases which may affect the estimated coefficients. Specifically, the empirical strategy utilizes a maximum likelihood (ML) estimation procedure that corrects for the possibility of endogenous selection into paid employment, relative to inactivity, by female workers (Heckman, 1979). The specifics of this estimation can be found in 
Appendix 1 (Table A3), from which it is evident that the OLS estimates do not suffer from selectivity bias due to non-random female participation. Appendix 1 also addresses the possibility that the OLS returns of male employees are affected by the omission of the self-employed from the analysis, since the latter constitute more than $25 \%$ of the original random sample of Greek men. ${ }^{12}$ No evidence of selectivity bias is found once again.

Though the LFS dataset does not contain appropriate variables that may be used as surrogates for the ability of individuals, an attempt is nonetheless made to include in the specification a proxy for the unobserved quality of students. This is done by exploiting the fact that at present the time of university study in Greece is open-ended, which has typically resulted in a large incidence of repeat year students. Indicator variables have thus been constructed for the 2002 wave only, in which available information exists, which differentiate university students in three distinct groupings as follows: (i) whether they are dropouts of the tertiary education system; (ii) whether they completed the study of their respective discipline within an 'normal' time interval; and (iii) whether it took much longer than average to gain the individual qualification. The details of this estimation procedure are contained in Appendix 2, from which it is predicted that university dropouts suffer from a significant reduction in wages (7-8\%), though no significant difference is found between categories (ii) and (iii). Furthermore, the estimates of the returns to university qualifications are largely unaffected by the inclusion in the wage equation of the ability-proxy variables.

\subsection{Returns to Subject of Degree in Greece}

Although there are significant rewards to a university education, the substantial diversity in the returns to particular degree programmes is masked in Table 3. This is evident from Table 4, which displays the estimates of returns to broad types of tertiary education degrees, disaggregated by gender, using as benchmark individuals who have completed secondary level education.

It is evident that the financial returns vary according to the type of degree that individuals study, all other things equal, bearing in mind that part of the differences in the returns may be due to inherent ability biases between their respective pools of graduates. Specifically, the estimates reveal that the 
subject that commands the largest monetary mark-up for men is Computer Science (53\%), followed by Medicine (45\%), Law (33\%) and Polytechnics (30\%). Graduates of Social Sciences, Economics and Business, as well as Physics and Mathematics are in the middle of the discipline rankings, commanding wage premiums of around 20-25\%. At the end of the spectrum are the subjects of Education (17\%), Agricultural Science (16\%), Physical Education (12\%) and Humanities (11\%), while the TEI courses are also ranked quite low (with Polytechnics and Applied Arts standing out). Interestingly, when accounting for the potential self-selection problem arising due to exclusion of the self-employed, evidence in favour of selectivity bias is found. Closer inspection reveals that such a bias arises as graduates from the fields of Polytechnics, Medicine and Law, in particular, have a higher probability of being in self-employment, so the OLS return to such fields of study are biased upwards (shown in Table A2 in the Appendix).

\section{[INSERT TABLE 4 HERE]}

The general conclusion that women have more to gain from a university education arises once again when comparing the returns to different types of degrees between the two sexes. Similar to their male counterparts, Medicine (55\%), Computer Science (44\%), Polytechnics (42\%) and Law (35\%) come up first in the discipline rankings of women. Physics and Mathematics (30\%), Social Sciences (28\%), Education (27\%), Humanities (26\%) and Economics and Business (20\%) courses follow with non-trivial monetary mark-ups. As in the case of men, the diplomas obtained from TEIs offer smaller wage premiums in comparison to those from AEIs. Notably, Computer Science, Economics and Business and Food Technology degrees are found to be more lucrative for male rather than female employees.

\subsection{Heterogeneity in the Returns to Degrees in Greece - Quantile Regressions}

In order to obtain a more comprehensive picture of the variation in the returns to higher education in Greece, Tables 5 and 6 present estimates of quantile regressions disaggregated by gender and publicprivate sector. It is interesting to notice at the outset that, as in Table 3, the median wage returns to the different academic disciplines are in general found to be higher in the private rather than the public 
sector in Greece. The degrees of Education and other Medical-related courses, however, constitute subjects in which the male financial returns in the public sector outweigh those of the private sector. Correspondingly for females, it is Law, Physical Education, Education and Applied Arts degrees that offer higher rewards in the public sector.

Wage returns of public sector graduates are also found to be lower at higher moments of the earnings distribution relative to those in private firms, which constitutes further evidence of the greater wage compression that is prevalent in Greek state jobs. As argued before, the higher wages of state employees at the lower tails of the distribution are the outcome of higher union coverage, promotions based on seniority, collective bargaining wage agreements and secure lifetime contracts (Papapetrou, 2006). Indeed, the wage compensation offered to additional years of tenure (for men) and to permanent contract holders was examined across all rungs of the wage distribution in the LFS dataset, and were found to be larger in the public than in the private sector. ${ }^{13}$ This is consistent with the evidence of Pouliakas and Theodossiou (2005), which showed that lower-paid workers in the Greek state enjoy higher job satisfaction relative to their private sector counterparts, given that they are more likely to be shielded from precarious employment contracts.

\section{[INSERT TABLES 5 \& 6 HERE]}

Importantly, the ranking of the academic subjects remains largely unaffected within quantiles. Nevertheless, an interesting pattern emerges given that for most of the fields, besides those of Medicine, Law, Economics and Business and Social Sciences, the impact of a degree on the earnings of public sector graduates is strong at the bottom quantiles, yet declines as one moves up the ability/wage distribution. As the reverse seems to hold true in the case of the private sector, this indicates that an educational degree acts as a substitute for ability in the public sector, as opposed to the private sector. Such a result is consistent with the fact that market forces are less likely to affect the remuneration of individuals who are employed at lower-level state jobs, given that the latter offer automatic wage premiums to job candidates who possess certain academic qualifications. As far as female university graduates are concerned, the evidence also seems to suggest that they are more likely 
to escape the phenomena of "sticky floors" and "glass ceilings" (Arulampalam et al., 2004) within public sector jobs.

\subsection{Heterogeneity in the Returns to Subject of Degree in Greece - Cohort Analysis}

As discussed in section 5, in order to make accurate comparisons of wage returns over time an analyst would require a survey of a specific cohort of individuals in alternative time periods. Nevertheless, given the absence of such data in Greece, the interaction between various cohorts of the LFS sample and the returns to educational degrees is examined in this section. This is done in an attempt to obtain useful insights about the effect of the rising educational attainment levels in Greece since the 1960s on graduate wages, and to examine whether differential labour demand and supply forces have resulted in divergent wage premiums to academic disciplines for different cohorts of the labour force.

Table 7 shows the estimated wage returns to fields of study for three different cohorts of the LFS, namely those whose year of birth is between the years 1950-1960, those between 1960-1970 and those born post-1970. ${ }^{14}$ The chosen separation of cohorts is made to approximately coincide with university graduates who entered the labour market in the 1970s, 1980s and 1990s, respectively.

As observed from Table 7, there has been a significant decline for both genders in the wage return to a tertiary degree in Greece in recent cohorts. This is indicative of a depressive wage effect following the increasing supply of university graduates in Greece over the years. Interestingly, one can observe further that the wage returns to the specific fields of Medicine, Law, Economics and Business, Social Sciences (for men) and Physical Education are those which have experienced the most marked decline in returns in later cohorts. The high and persistent returns to Polytechnic and Computer Science degrees, and the decreasing premiums to Medicine and Law courses, gives some credence to assertions claiming that there has been a distortionary distribution of degree holders across academic fields in Greece in recent decades.

[INSERT TABLE 7 HERE] 


\section{Discussion}

From the empirical results of this paper, one can draw the conclusion that despite the persistent positive returns of higher education in Greece, fears regarding the saturated job market prospects of recent university graduates appear to have materialized in terms of lower mean wage returns. This is found to be particularly the case for those fields which have experienced a greater "overflow" of degree holders in the labour market, such as Medicine and Law. Nevertheless, the rankings of wage premia across different subjects suggest that the latter are amongst the most lucrative careers in Greece, along with Polytechnics and Computer Science. Indeed, the bright prospects of Computer Science, in terms of both the high financial returns and low probability of unemployment (Livanos, 2008[a]), is evidence of the fact that the demand for skills associated with new technologies in Greece has outpaced the available supply of such graduates. In contrast, the lower wage prospects of graduates of Humanities, Physical Education and Education degrees suggests that these fields have a more marginal role to play in the face of a rising service sector and a shrinking public sector in the Greek economy (which has traditionally supported their wages). Finally, for graduates of most TEIs a smaller compensation in the labour market is predicted.

Efficient career counselling that emphasizes the wage prospects of the various disciplines, as suggested in this paper, may thus allow students to undertake informed decisions about their higher education degrees, and to stem the misallocation of talent towards subjects that have poor labour market prospects. The estimates of this study may also inform the design of future educational policy and reforms, for instance by encouraging higher education institutes to offer more courses in promising subjects such as Computer and IT sciences. There is also an apparent need for further development and strengthening of vocational and technological education in Greece, as this could provide a crucial alternative to those students whose aptitudes lie in the technical rather than the academic sphere, but who are at present discouraged from attending the existing TEIs.

To that end, several features of the Greek higher education system that inhibit the aforementioned reforms need to be taken into account (OECD, 2007). These include the very low opportunity costs of university study due to the free provision of higher education, the lack of incentives for enrolment to 
courses at later stages of life, and the open-ended nature of university tenure that permits undergraduate students to take exams as many times as they wish until graduation. All of these factors encourage students to study courses which do not necessarily comprise their most preferred choice and/or correspond with their particular set of tastes/abilities. Possible avenues that may be explored to enhance the allocative efficiency of the degree conferral process include (among others) the introduction of tuition fees along with unregulated entry to tertiary education (subject to the provision of effective support to the financially disadvantaged), strengthening of the Open University and provision of vocational courses, and limitations to the numbers of years that individuals can remain at university. These measures may empower students' decision making in their choice of field of study and enhance the reflexes of universities to the changing demands of the economy.

Though to a large extent controversial with the Greek public opinion, the foundation of non-profit privately-run universities in Greece alongside public sector ones could also result in a better allocation of university graduates across fields in the future. This may be achieved with private Schools most likely focussing on the provision of degrees which are market-oriented, and the public ones ensuring an adequate supply of graduates from other less financially-rewarding disciplines which are, nevertheless, vital for the operation of any economy and society. It might also be the case that such an arrangement will stem the 'haemorrhage' of young Greek students to foreign universities (OECD, 2002). ${ }^{15}$

\section{Conclusions}

This study estimates wage returns to different academic disciplines in the Greek labour market using recently available data from the LFS. The estimated returns are found to vary considerably across the various degree subjects examined, with important gender and public/private sector differences observed. Evidence is also presented that supply-side forces are exerting pressure on the wage returns of disciplines in which an apparent oversupply of graduates exists.

Confirmation of the above conclusions, in particular of any trends in wage premiums, requires further investigation with an adequate time-series of data. In general, there is a lack of appropriate 
educational-specific datasets in Greece that may permit the study of potential selectivity issues or the interaction among socio-economic background variables and wage outcomes of specific cohorts of graduates. There is therefore an evident need for the development of such sources of data in the future within Greece.

What emerges clearly from the analysis of this paper is that future educational reforms in Greece need to take into account the heterogeneous nature of the returns to alternative academic disciplines and use them as a guide to inform students' curriculum choices, and as impetus for the achievement of a more efficient match between the supply and demand of tertiary education graduates.

\section{Acknowledgments}

The authors would like to thank the Department of Economics of the University of Cyprus, which provided excellent facilities to Dr. Konstantinos Pouliakas at the time of his Invited Lectureship at the Institution, during which the first draft of the paper was written. Special thanks are also given to two anonymous referees of this journal, Dr. Alexandros Zangelidis and Professor I. Theodossiou for helpful comments, while participants at the $2^{\text {nd }}$ International Conference on Educational Economics (Athens, August 2008), and the $8^{\text {th }}$ Conference on Research in Economics and Econometric Theory (Tinos, July, 2009) offered useful insights.

\section{References}

Arulampalam, W., Booth, A. and Bryan, M.L. (2004), 'Is there a glass ceiling over Europe? Exploring the gender pay gap across the wage distribution', IZA Discussion Paper, No. 1373, October.

Becker, S.G. (1964), Human Capital: A theoretical and empirical analysis with special reference to education, $3^{\text {rd }}$ ed., University of Chicago Press: Chicago.

Ben-Porath, Y. (1967), 'The production of human capital and the life cycle of earnings', Journal of Political Economy, Vol. 75, pp. 352-365.

Blackaby, D., Murphy, P. and O’Leary, N. (1999), 'Graduate Earnings in Great Britain: A Matter of Degree?’, Applied Economics Letters, Vol. 6, pp. 311-315.

Blaug, M. (1976), 'Human Capital Theory : A Slightly Jaundiced Survey’, Journal of Economic Literature, Vol. 14, pp. 827-855.

Blundell, R.L., Dearden, L., Goodman, A. and Reed, H. (2000), 'The Returns to Higher Education in Britain : Evidence from a British Cohort', Economic Journal, Vol. 110, Vo. 461, F82-F99.

Bratti, M., Naylor, R. and Smith, J. (2008), 'Heterogeneities in the Returns to Degrees : Evidence from the British Cohort Study 1970’, IZA Discussion Paper no. 1631. 
Buchinsky, M. (1994), 'Changes in the US Wage Structure 1963-1987. An Application of Quantile Regression;, Econometrica, Vol. 62, No. 2, pp. 405-458.

Buchinksy, M. (1998), 'The Dynamics of Changes in the Female Wage Distribution in the USA: A Quantile Regression Approach', Journal of Applied Econometrics, Vol. 13, No. 1, pp. 1-30.

Buchinksy, M. (2001), 'Quantile Regression with Sample Selection: Estimating Women’s Return to Education in the US', Empirical Economics, Vol. 26, pp. 87-113.

Card, D. (1999), 'The causal effect of education on earnings' in: O. Ashenfelter and D. Card (eds.), Handbook of Labor Economics, Vol. 3A, p. 1801-1863, Amsterdam: Elsevier.

Cholezas, I. and Tsakloglou, P. (1999), 'Private returns to education in Greece: A review of the empirical literature', in R.Asplund and P.T. Pereira (eds) Returns to human capital in Europe: A literature review, ETLA, Helsinki.

Cholezas, I. and Tsakloglou, P. (2006), 'Gender Earnings Differentials in the Greek Labour Market', Economic Policy Studies, forthcoming.

Dolton, P. and Marcenaro-Gutierrez, O. (2009), 'Overeducation Across Europe' in: Dolton, P., Asplund, R. and Barth, E. (eds.), Education and Inequality Across Europe, Ch. 4, Cheltenham, Northampton, Mass : Edward Elgar Publishing.

European Commission (1996), Labour Market Studies: Greece, Employment and Social Affairs, Luxembourg.

Finnie, R. and Frenette, M. (2003), 'Earnings Differences by Major Field of Study : Evidence From Three Cohorts of Recent Canadian Graduates', Economics of Education Review, Vol. 22, No. 2, pp. 179-192.

Fyntanidoy, E. (2001), 'Doctor Inflation in Greece’, To Bhma (Greek newspaper), 17 June, No. B13289A421.

Greenaway, D. and Hayes, M. (2003), 'Funding Higher Education in the UK: The Role of Fees and Loans', Economic Journal, Vol. 113: F150-F166.

Grubb, W.N. (1992), 'The Economic Return to Baccalaureate Degrees: New Evidence from the Class of 1972', Review of Higher Education, Vol. 15, No. 2, pp. 213-231.

Harmon, C., Walker I. And Westergaard-Nielsen, N. (eds.) (2001), Education and Earnings in Europe: A CrossCountry Analysis of the Returns to Education, Cheltenham, Northampton, Mass: Edward Elgard Publishing.

Heckman, J.J. (1979), 'Sample Selection Bias as a Specification Error’, Econometrica, Vol. 47, pp. 153-161.

Heckman, J., Lochner, L., and Todd, P. (2006), “Earnings Functions, Rates of Return and Treatment Effects: The

Mincer Equation and Beyond” in E. Hanushek and F. Welch (eds.), Handbook of the Economics of Education. Amsterdam: North-Holland.

Kanellopoulos, C.N. (1997), 'Public-private wage differentials in Greece', Applied Economics, Vol. 29, pp. 1023-1032.

Kanellopoulos, C.N., Mitrakos, T. and Mavromaras, K.G. (2003), Education and Labour Market, Center for Planning and Economic Research, Scientific Studies no. 50: Athens (in Greek).

Katsanevas, (2002), Professions of the Future and the Past, Patakis Press : Athens (in Greek).

Kelly, E., O, O’Connell, P. and Smith, E., 'The Economic Returns to Field of Study and Competencies among Higher Education Graduates in Ireland', ESRI working paper No. 242, May.

Lambropoulos, H. and Psacharopoulos, G. (1992), 'Educational Expansion and Earnings Differentials in Greece’, Comparative Education Review, Vol. 36, p. 52-70. 
Leslie, D. (2003), 'Using Success to Measure Quality in British Higher Education: Which Subjects Attract the Best-Qualified Students?’, Journal of the Royal Statistical Society, Vol. 166, pp. 329-347.

Livanos, I. (2008[a]), 'Exploring graduate prospects by field of study : an analysis of the Greek labour market', unpublished mimeo, University of Warwick.

Livanos, I. (2008[b]), 'The wage - local unemployment relationship in a highly regulated labour market: Greece', Regional Studies, forthcoming.

Livanos, I. and Pouliakas, K. (2009), 'The Gender Wage Gap as a Function of Educational Degree Choices in Greece’, MPRA Working Paper No. 14168.

Machin, S. and Puhani, P.A. (2003), 'Subject of degree and the gender wage differential: Evidence for the UK and Germany’, Economics Letters, Vol. 79, pp. 393-400.

Machin, S. and McNally, S. (2007), ‘Tertiary Education Systems and Labour Markets’, Education and Training Policy Division, OECD.

Magoula, T. and Psacharopoulos, G. (1999), 'Schooling and monetary rewards in Greece: an over-education false alarm?', Applied Economics, Vol. 31, pp. 1589-1597.

Mincer, J. (1974), Schooling, experience and earnings, Columbia University Press: NY.

Mroz, T.A. (1987), 'The Sensitivity of an Empirical Model of Married Women's Hours of Work to Economic and Statistical Assumptions', Econometrica, Vol. 55, pp. 765-799.

OECD (2002), 'Trade of Educational Services Forum', 23-24 May, Centre for Educational Research and Innovation, Washington, DC.

OECD (2005), Economic Surveys: Greece, OECD: Paris.

OECD (2007), Economic Surveys: Greece, OECD: Paris.

OECD (2008), Education at a Glance, OECD: Paris.

OECD (2009), Education Online Database, www.oecd.org/education/database

O’Leary. N.C. and Sloane, P.J. (2005), ‘The Return to a University Education in Great Britain', National Institute Economic Review, Vol. 193, No. 1, pp. 75-89.

Papamatthaioy, M. (2002), ‘500.000 students in Greek AEI’, To Bhma (Greek newspaper), 20 Oct, No. B13694A411.

Papapetrou, E. (2004), 'Gender Wage Differentials in Greece’, Bank of Greece Economic Bulletin, Vol. 23, pp. 47-64.

Papapetrou, E. (2006), 'The unequal distribution of the public-private sector wage gap in Greece: evidence from quantile regression', Applied Economics Letters, Vol. 13, pp. 205-210.

Patrinos, H. (1997). 'Overeducation in Greece', International Review of Education, Vol. 43, No. 2/3, pp. 203223.

Pereira, P. and Martins, P. (2004), 'Returns to Education and Wage Equations’, Applied Economics, Vol. 36, pp. 525-531.

Pouliakas, K. and Theodossiou, I. (2005), 'Socio-Economic Differences in the Perceived Quality of High and Low-Paid Jobs in Greece’, Bank of Greece Economic Bulletin, Vol. 24, January, p. 91-132.

Prodromidis, K.P. and Prodromidis, P.I. (2007), 'Returns to education: the Greek experience, 1988-1999', Applied Economics, pp. 1-8, iFirst. 
Psacharopoulos, G. (1990), Education in Greece: A Modern Tragedy, Sideris: Athens.

Psacharopoulos, G. (1994), 'Returns to investment in education: A global update', World Development, Vol. 22, pp. 1325-1343.

Psacharopoulos, G. (2003), ‘The social cost of an outdated law: Article 16 of the Greek constitution', European Journal of Law and Economics, Vol. 16, pp. 123-137.

Rumberger, R.W. and Thomas, S.L. (1993), 'The Economic Returns to College Major, Quality and Performance: A Multilevel Analysis of Recent Graduates’, Economics of Education Review, Vol. 12, No. 1, pp. 1-19.

Tsakloglou, P. and Cholezas, I. (2005), 'Education and Inequality in Greece’, IZA Discussion Paper, No. 1582, May.

Walker, I. and Zhu, Y. (2001), The Returns to Education: Evidence from the Labour Force Surveys, Research Report for Dept of Education and Skills, No. RR313, November. 
Table 1 Descriptive Statistics of Educational Qualifications and Academic Disciplines in Greece, 2002-2003, LFS

\begin{tabular}{|c|c|c|c|c|}
\hline & \multirow[b]{2}{*}{$\mathbf{N}$} & \multirow[b]{2}{*}{$\%$} & \multicolumn{2}{|c|}{ Wage } \\
\hline & & & $\begin{array}{c}\text { Mean } \\
(€)\end{array}$ & s.d \\
\hline \multicolumn{5}{|l|}{ All sample } \\
\hline PhD & 108 & 0.37 & 1272 & 459 \\
\hline Masters & 187 & 0.63 & 1103 & 484 \\
\hline $\mathrm{AEI}$ & 5,924 & 20.10 & 978 & 345 \\
\hline TEI & 1,184 & 4.02 & 887 & 290 \\
\hline $\begin{array}{l}\text { Post-secondary } \\
\text { (IEK/Colleges) }\end{array}$ & 2,836 & 9.62 & 793 & 354 \\
\hline $\begin{array}{l}\text { Other (e.g. military } \\
\text { schools) }\end{array}$ & 598 & 2.03 & 1039 & 299 \\
\hline Secondary & 12,943 & 43.91 & 784 & 292 \\
\hline Primary & 5,696 & 19.32 & 749 & 289 \\
\hline Total & 29,476 & 100 & 831 & 325 \\
\hline \multicolumn{5}{|l|}{ Univ. graduates } \\
\hline \multicolumn{5}{|l|}{ AEI } \\
\hline Polytechnics & 599 & 8.43 & 1097 & 399 \\
\hline Computing Science & 52 & 0.73 & 1052 & 344 \\
\hline Agricultural Science & 180 & 2.53 & 976 & 280 \\
\hline Physics and Maths & 635 & 8.93 & 976 & 295 \\
\hline Medicine & 380 & 5.35 & 1230 & 422 \\
\hline Law & 239 & 3.36 & 1083 & 446 \\
\hline $\begin{array}{l}\text { Economics \& } \\
\text { Business }\end{array}$ & 1,491 & 20.98 & 942 & 375 \\
\hline Social Sciences & 123 & 1.73 & 975 & 371 \\
\hline Humanities & 1,010 & 14.21 & 893 & 280 \\
\hline Physical Education & 273 & 3.84 & 851 & 271 \\
\hline Education & 942 & 13.25 & 960 & 241 \\
\hline \multicolumn{5}{|l|}{ TEI } \\
\hline Polytechnics & 521 & 7.33 & 950 & 318 \\
\hline Agricultural Science & 71 & 1.00 & 790 & 236 \\
\hline Food Technology & 32 & 0.45 & 817 & 315 \\
\hline Librarianship & 11 & 0.15 & 750 & 216 \\
\hline Medical-related & 513 & 7.22 & 216 & 258 \\
\hline Applied Arts & 36 & 0.51 & 873 & 228 \\
\hline Total & 7,108 & 100 & 962 & 338 \\
\hline
\end{tabular}


Table 2

Descriptive Statistics of Employee Characteristics, Greece, 2002-2003, LFS

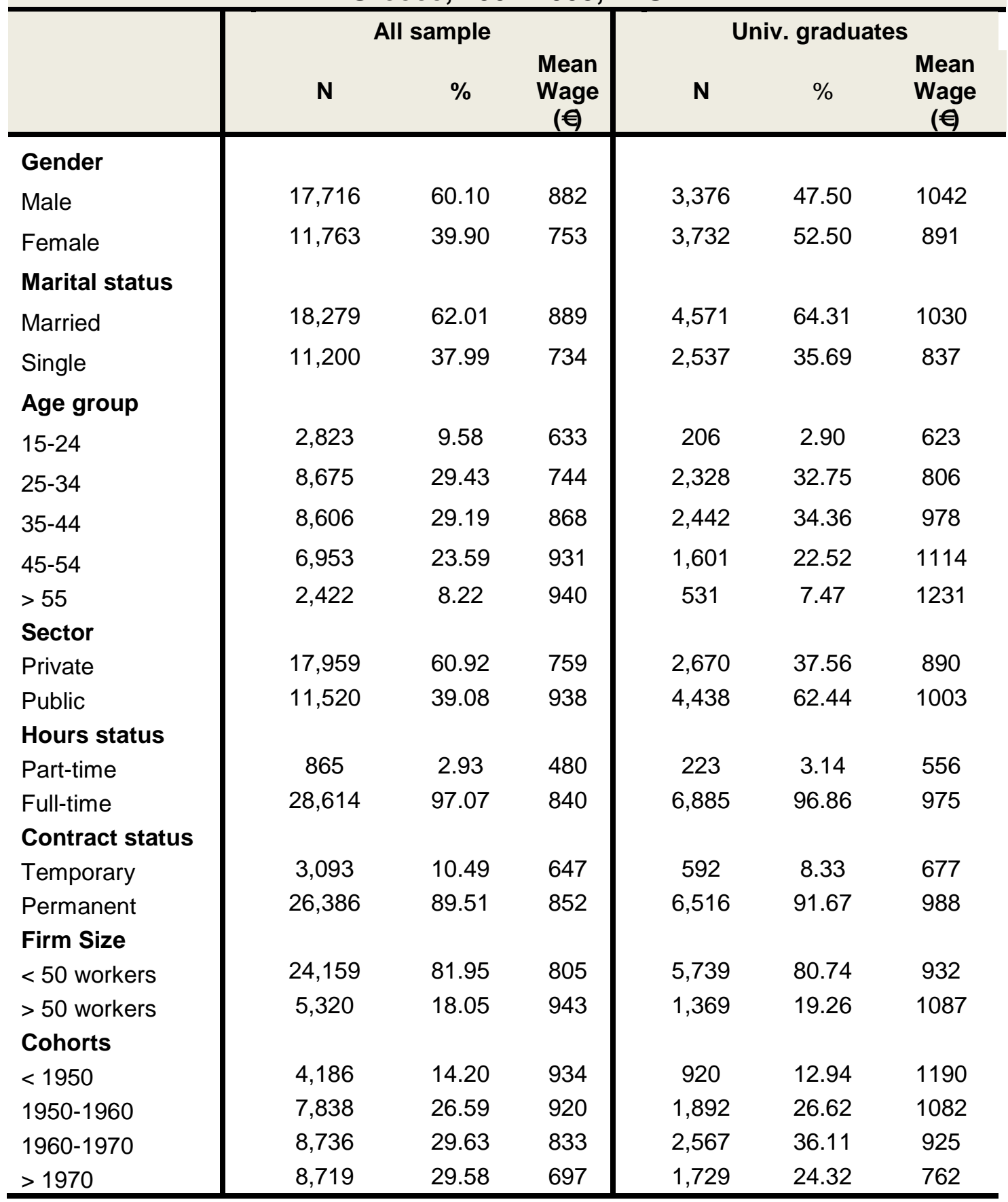


Table 3 Wage Premiums to Educational Qualifications in Greece, 2002-2003, LFS

\begin{tabular}{|c|c|c|c|c|c|c|}
\hline & \multicolumn{3}{|c|}{ Males } & \multicolumn{3}{|c|}{ Females } \\
\hline & All & Public & Private & All & Public & Private \\
\hline Qualifications & & & & & & \\
\hline $\mathrm{PhD}$ & $49.33 \%$ & $43.91 \%$ & $27.12 \%$ & $51.29 \%$ & $39.65 \%$ & $24.48 \%$ \\
\hline Masters & $39.38 \%$ & $38.13 \%$ & $36.62 \%$ & $46.52 \%$ & $33.91 \%$ & $51.59 \%$ \\
\hline AEI & $24.11 \%$ & $17.23 \%$ & $26.62 \%$ & $29.05 \%$ & $22.88 \%$ & $25.11 \%$ \\
\hline TEI & $14.11 \%$ & $8.33 \%$ & $16.30 \%$ & $17.59 \%$ & $7.90 \%$ & $15.95 \%$ \\
\hline $\begin{array}{l}\text { Post-secondary } \\
\text { (IEK/Colleges) }\end{array}$ & $6.82 \%$ & $1.51 \%$ & $8.87 \%$ & $5.65 \%$ & $5.87 \%$ & $4.81 \%$ \\
\hline $\begin{array}{l}\text { Other (e.g. } \\
\text { military } \\
\text { schools) }\end{array}$ & $23.00 \%$ & $15.14 \%$ & $21.29 \%$ & $30.87 \%$ & $19.72 \%$ & $-1.19 \%$ \\
\hline Primary & $-9.61 \%$ & $-11.40 \%$ & $-6.76 \%$ & $-14.44 \%$ & $-21.96 \%$ & $-9.34 \%$ \\
\hline
\end{tabular}


Table 4 Wage Premiums and Ranking of Academic Disciplines in Greece, 2002-2003, LFS

\begin{tabular}{|c|c|c|c|c|}
\hline & Males & $\begin{array}{c}\text { Rank } \\
\text { (Males) }\end{array}$ & Females & $\begin{array}{c}\text { Rank } \\
\text { (Females) }\end{array}$ \\
\hline \multicolumn{5}{|l|}{ AEI } \\
\hline Polytechnics & $29.95 \%$ & 4 & $42.19 \%$ & 3 \\
\hline Computer Science & $52.65 \%$ & 1 & $44.48 \%$ & 2 \\
\hline Agricultural Science & $16.42 \%$ & 9 & $27.38 \%$ & 7 \\
\hline Physics \& Maths & $19.72 \%$ & 7 & $30.21 \%$ & 5 \\
\hline Medicine & $44.92 \%$ & 2 & $54.65 \%$ & 1 \\
\hline Law & $33.38 \%$ & 3 & $34.45 \%$ & 4 \\
\hline Economics \& Business & $21.53 \%$ & 6 & $20.44 \%$ & 12 \\
\hline Social Sciences & $24.48 \%$ & 5 & $28.27 \%$ & 6 \\
\hline Humanities & $11.18 \%$ & 14 & $25.73 \%$ & 9 \\
\hline Physical Education & $11.85 \%$ & 13 & $20.68 \%$ & 11 \\
\hline Education & $17.47 \%$ & 8 & $27.25 \%$ & 8 \\
\hline \multicolumn{5}{|l|}{ TEI } \\
\hline Polytechnics & $15.72 \%$ & 10 & $17.23 \%$ & 14 \\
\hline Agricultural Science & $6.93 \%$ & 16 & $12.75 \%$ & 15 \\
\hline Food Technology & $12.41 \%$ & 12 & $4.19 \%$ & 17 \\
\hline Librarianship & NA & NA & $10.63 \%$ & 16 \\
\hline Medical-related & $9.53 \%$ & 15 & $18.18 \%$ & 13 \\
\hline Applied Arts & $14.34 \%$ & 11 & $21.65 \%$ & 10 \\
\hline
\end{tabular}


Table 5 Wage Returns to Academic Disciplines in Greece, Quantile Regressions, Males, 2002-2003, LFS

\begin{tabular}{|c|c|c|c|c|c|c|c|c|c|c|}
\hline & \multicolumn{5}{|c|}{ Public } & \multicolumn{5}{|c|}{ Private } \\
\hline & $(1)$ & $(2)$ & (3) & $(4)$ & (5) & (6) & $(7)$ & (8) & (9) & $(10)$ \\
\hline & 0.1 & 0.25 & 0.5 & 0.75 & 0.9 & 0.1 & 0.25 & 0.5 & 0.75 & 0.9 \\
\hline AEI & $\begin{array}{c}0.075^{\star \star \star} \\
(0.012)\end{array}$ & $\begin{array}{c}0.181^{\star * *} \\
(0.010)\end{array}$ & $\begin{array}{c}0.093^{\star * \star} \\
(0.008)\end{array}$ & $\begin{array}{c}0.159 * \star * \\
(0.008)\end{array}$ & $\begin{array}{c}0.163^{\star * *} \\
(0.014)\end{array}$ & $\begin{array}{c}0.186^{\star * *} \\
(0.022)\end{array}$ & $\begin{array}{c}0.193^{\star \star \star} \\
(0.017)\end{array}$ & $\begin{array}{c}0.222^{\star \star *} \\
(0.008)\end{array}$ & $\begin{array}{c}0.269 * * * \\
(0.010)\end{array}$ & $\begin{array}{c}0.418^{\star \star *} \\
(0.016)\end{array}$ \\
\hline Polytechnics & $\begin{array}{l}0.091^{\star \star *} \\
(0.022)\end{array}$ & $\begin{array}{c}0.219 * * * \\
(0.018)\end{array}$ & $\begin{array}{c}0.113^{\star \star \star} \\
(0.011)\end{array}$ & $\begin{array}{c}0.170 \star \star \star \\
(0.011)\end{array}$ & $\begin{array}{c}0.065^{\star \star *} \\
(0.013)\end{array}$ & $\begin{array}{c}0.330 * * * \\
(0.040)\end{array}$ & $\begin{array}{c}0.345^{\star \star \star} \\
(0.021)\end{array}$ & $\begin{array}{c}0.295^{\star \star \star} \\
(0.019)\end{array}$ & $\begin{array}{c}0.336 * * * \\
(0.018)\end{array}$ & $\begin{array}{c}0.536 * \star \star \\
(0.030)\end{array}$ \\
\hline Computer Science & $\begin{array}{c}0.506^{\star \star \star} \\
(0.036)\end{array}$ & $\begin{array}{c}0.396^{\star \star *} \\
(0.075)\end{array}$ & $\begin{array}{c}0.341^{\star \star \star} \\
(0.047)\end{array}$ & $\begin{array}{c}0.341^{\star \star \star} \\
(0.047)\end{array}$ & $\begin{array}{c}0.229 * * * \\
(0.020)\end{array}$ & $\begin{array}{c}0.494^{\star \star *} \\
(0.111)\end{array}$ & $\begin{array}{c}0.438 * \star \star \\
(0.056)\end{array}$ & $\begin{array}{c}0.401^{\star \star \star} \\
(0.054)\end{array}$ & $\begin{array}{c}0.420 * * * \\
(0.049)\end{array}$ & $\begin{array}{c}0.617^{\star * \star} \\
(0.083)\end{array}$ \\
\hline Agricultural Science & $\begin{array}{c}0.029 \\
(0.035)\end{array}$ & $\begin{array}{c}0.084^{\star * *} \\
(0.027)\end{array}$ & $\begin{array}{c}0.051^{\star \star \star} \\
(0.016)\end{array}$ & $\begin{array}{c}0.020 \\
(0.016)\end{array}$ & $\begin{array}{c}0.008 \\
(0.018)\end{array}$ & $\begin{array}{c}0.293^{\star \star \star} \\
(0.102)\end{array}$ & $\begin{array}{c}0.286 \star \star \star \\
(0.056)\end{array}$ & $\begin{array}{c}0.276^{\star \star \star} \\
(0.052)\end{array}$ & $\begin{array}{c}0.306^{\star * *} \\
(0.049)\end{array}$ & $\begin{array}{c}0.450 \text { *** } \\
(0.076)\end{array}$ \\
\hline Physics \& Maths & $\begin{array}{c}0.061^{\star \star *} \\
(0.023)\end{array}$ & $\begin{array}{c}0.152^{\star \star *} \\
(0.017)\end{array}$ & $\begin{array}{c}0.065^{\star \star *} \\
(0.011)\end{array}$ & $\begin{array}{c}0.067^{\star * *} \\
(0.011)\end{array}$ & $\begin{array}{c}0.039 * * * \\
(0.012)\end{array}$ & $\begin{array}{c}0.258^{\star * *} \\
(0.056)\end{array}$ & $\begin{array}{c}0.184^{\star \star *} \\
(0.028)\end{array}$ & $\begin{array}{c}0.199 * * * \\
(0.026)\end{array}$ & $\begin{array}{c}0.185^{\star * *} \\
(0.024)\end{array}$ & $\begin{array}{c}0.313^{\star \star *} \\
(0.041)\end{array}$ \\
\hline Medicine & $\begin{array}{c}0.281^{\star \star *} \\
(0.026)\end{array}$ & $\begin{array}{c}0.299 * * * \\
(0.020)\end{array}$ & $\begin{array}{c}0.295^{\star \star \star} \\
(0.012)\end{array}$ & $\begin{array}{c}0.336^{\star \star \star} \\
(0.012)\end{array}$ & $\begin{array}{c}0.438 * * * \\
(0.014)\end{array}$ & $\begin{array}{c}0.450 * \star \star \\
(0.114)\end{array}$ & $\begin{array}{c}0.346^{\star \star \star} \\
(0.054)\end{array}$ & $\begin{array}{c}0.403^{\star \star \star} \\
(0.055)\end{array}$ & $\begin{array}{c}0.331^{* * *} \\
(0.051)\end{array}$ & $\begin{array}{c}0.388 * \star \star \\
(0.086)\end{array}$ \\
\hline Law & $\begin{array}{c}0.060 \\
(0.049)\end{array}$ & $\begin{array}{c}0.276^{\star \star *} \\
(0.037)\end{array}$ & $\begin{array}{c}0.247^{\star * \star} \\
(0.023)\end{array}$ & $\begin{array}{c}0.263^{\star \star \star} \\
(0.023)\end{array}$ & $\begin{array}{c}0.395^{\star \star *} \\
(0.027)\end{array}$ & $\begin{array}{l}0.215^{\star \star} \\
(0.098)\end{array}$ & $\begin{array}{c}0.277^{\star * \star} \\
(0.050)\end{array}$ & $\begin{array}{c}0.272^{\star \star \star} \\
(0.045)\end{array}$ & $\begin{array}{c}0.410^{\star * *} \\
(0.044)\end{array}$ & $\begin{array}{c}0.600^{\star * \star} \\
(0.072)\end{array}$ \\
\hline Economics \& Business & $\begin{array}{c}0.058^{\star \star \star} \\
(0.020)\end{array}$ & $\begin{array}{c}0.121^{\star \star *} \\
(0.015)\end{array}$ & $\begin{array}{c}0.083^{\star \star \star} \\
(0.009)\end{array}$ & $\begin{array}{c}0.177^{\star \star \star} \\
(0.009)\end{array}$ & $\begin{array}{c}0.203^{\star * \star} \\
(0.011)\end{array}$ & $\begin{array}{c}0.149 * \star \star \\
(0.030)\end{array}$ & $\begin{array}{c}0.143^{\star \star \star} \\
(0.015)\end{array}$ & $\begin{array}{c}0.208^{\star \star \star} \\
(0.014)\end{array}$ & $\begin{array}{c}0.253^{\star * \star} \\
(0.013)\end{array}$ & $\begin{array}{c}0.422^{\star \star \star} \\
(0.022)\end{array}$ \\
\hline Social Sciences & $\begin{array}{c}0.321^{\star \star *} \\
(0.062)\end{array}$ & $\begin{array}{c}0.250 * \star * \\
(0.048)\end{array}$ & $\begin{array}{c}0.142^{\star * *} \\
(0.031)\end{array}$ & $\begin{array}{c}0.192^{\star * *} \\
(0.030)\end{array}$ & $\begin{array}{c}0.389 * * * \\
(0.034)\end{array}$ & $\begin{array}{l}0.219 * * \\
(0.099)\end{array}$ & $\begin{array}{c}0.196 * \star * \\
(0.062)\end{array}$ & $\begin{array}{c}0.203^{\star \star *} \\
(0.059)\end{array}$ & $\begin{array}{c}0.084 \\
(0.052)\end{array}$ & $\begin{array}{l}0.147^{* *} \\
(0.074)\end{array}$ \\
\hline Humanities & $\begin{array}{c}0.032 \\
(0.027)\end{array}$ & $\begin{array}{c}0.080^{\star * *} \\
(0.021)\end{array}$ & $\begin{array}{c}0.045^{\star \star \star} \\
(0.013)\end{array}$ & $\begin{array}{l}0.026 \star \star \\
(0.013)\end{array}$ & $\begin{array}{c}0.021 \\
(0.014)\end{array}$ & $\begin{array}{c}0.089 \\
(0.089)\end{array}$ & $\begin{array}{c}0.071 \\
(0.045)\end{array}$ & $\begin{array}{l}0.095^{\star \star} \\
(0.041)\end{array}$ & $\begin{array}{l}0.083^{\star *} \\
(0.038)\end{array}$ & $\begin{array}{c}0.070 \\
(0.067)\end{array}$ \\
\hline Physical Education & $\begin{array}{c}0.027 \\
(0.033)\end{array}$ & $\begin{array}{c}0.091^{\star * *} \\
(0.026)\end{array}$ & $\begin{array}{c}0.043^{\star * *} \\
(0.016)\end{array}$ & $\begin{array}{c}0.042^{\star * *} \\
(0.016)\end{array}$ & $\begin{array}{c}0.014 \\
(0.018)\end{array}$ & $\begin{array}{c}0.083 \\
(0.076)\end{array}$ & $\begin{array}{c}0.121^{\star * *} \\
(0.039)\end{array}$ & $\begin{array}{c}0.136^{\star \star *} \\
(0.035)\end{array}$ & $\begin{array}{c}0.059 * \\
(0.033)\end{array}$ & $\begin{array}{c}-0.027 \\
(0.056)\end{array}$ \\
\hline
\end{tabular}




\begin{tabular}{|c|c|c|c|c|c|c|c|c|c|c|}
\hline Education & $\begin{array}{c}0.070^{\star \star \star} \\
(0.023)\end{array}$ & $\begin{array}{c}0.114^{\star \star \star} \\
(0.017)\end{array}$ & $\begin{array}{c}0.054^{\star \star \star} \\
(0.011)\end{array}$ & $\begin{array}{c}0.034^{\star \star \star} \\
(0.011)\end{array}$ & $\begin{array}{c}0.035^{\star \star \star} \\
(0.012)\end{array}$ & $\begin{array}{c}0.066 \\
(0.150)\end{array}$ & $\begin{array}{l}-0.041 \\
(0.081)\end{array}$ & $\begin{array}{c}0.027 \\
(0.073)\end{array}$ & $\begin{array}{c}0.026 \\
(0.071)\end{array}$ & $\begin{array}{l}-0.064 \\
(0.112)\end{array}$ \\
\hline TEI & $\begin{array}{c}0.063^{\star \star \star} \\
(0.023)\end{array}$ & $\begin{array}{c}0.112^{\star \star \star} \\
(0.019) \\
\end{array}$ & $\begin{array}{c}0.045^{\star \star \star} \\
(0.015) \\
\end{array}$ & $\begin{array}{c}0.076^{\star \star \star} \\
(0.016) \\
\end{array}$ & $\begin{array}{c}0.077^{\star \star *} \\
(0.025) \\
\end{array}$ & $\begin{array}{c}0.177^{\star \star \star} \\
(0.038) \\
\end{array}$ & $\begin{array}{c}0.141^{\star \star \star} \\
(0.029) \\
\end{array}$ & $\begin{array}{c}0.154^{\star \star \star} \\
(0.014) \\
\end{array}$ & $\begin{array}{c}0.128^{\star \star \star} \\
(0.018) \\
\end{array}$ & $\begin{array}{c}0.191^{\star \star \star} \\
(0.028) \\
\end{array}$ \\
\hline Polytechnic & $\begin{array}{l}0.059^{\star \star} \\
(0.024)\end{array}$ & $\begin{array}{c}0.081^{\star \star \star} \\
(0.019)\end{array}$ & $\begin{array}{c}0.048^{\star \star \star} \\
(0.012)\end{array}$ & $\begin{array}{c}0.043^{\star \star \star} \\
(0.012)\end{array}$ & $\begin{array}{c}0.037^{\star \star \star} \\
(0.013)\end{array}$ & $\begin{array}{c}0.200^{\star \star \star} \\
(0.040)\end{array}$ & $\begin{array}{c}0.175^{\star \star \star} \\
(0.020)\end{array}$ & $\begin{array}{c}0.176^{\star \star \star} \\
(0.019)\end{array}$ & $\begin{array}{c}0.118^{\star \star \star} \\
(0.018)\end{array}$ & $\begin{array}{c}0.215^{\star \star \star} \\
(0.030)\end{array}$ \\
\hline Agricultural Science & $\begin{array}{l}-0.000 \\
(0.053)\end{array}$ & $\begin{array}{c}0.032 \\
(0.053)\end{array}$ & $\begin{array}{c}0.026 \\
(0.033)\end{array}$ & $\begin{array}{c}0.046 \\
(0.031)\end{array}$ & $\begin{array}{c}0.009 \\
(0.029)\end{array}$ & $\begin{array}{c}0.157 \\
(0.114)\end{array}$ & $\begin{array}{c}0.214^{\star \star \star} \\
(0.070)\end{array}$ & $\begin{array}{c}0.065 \\
(0.064)\end{array}$ & $\begin{array}{c}0.024 \\
(0.061)\end{array}$ & $\begin{array}{l}-0.019 \\
(0.086)\end{array}$ \\
\hline Food Technology & $\begin{array}{c}0.006 \\
(0.044)\end{array}$ & $\begin{array}{l}0.204^{\star *} \\
(0.095)\end{array}$ & $\begin{array}{c}0.043 \\
(0.060)\end{array}$ & $\begin{array}{l}-0.067 \\
(0.060)\end{array}$ & $\begin{array}{c}0.428^{\star \star \star} \\
(0.024)\end{array}$ & $\begin{array}{c}0.042 \\
(0.067)\end{array}$ & $\begin{array}{c}0.044 \\
(0.088)\end{array}$ & $\begin{array}{l}0.150^{\star} \\
(0.084)\end{array}$ & $\begin{array}{c}0.030 \\
(0.077)\end{array}$ & $\begin{array}{c}0.081 \\
(0.050)\end{array}$ \\
\hline Medical-related & $\begin{array}{l}0.117^{\star *} \\
(0.045)\end{array}$ & $\begin{array}{c}0.119^{\star \star \star} \\
(0.036)\end{array}$ & $\begin{array}{l}0.047^{\star *} \\
(0.022)\end{array}$ & $\begin{array}{c}0.016 \\
(0.022)\end{array}$ & $\begin{array}{c}0.029 \\
(0.025)\end{array}$ & $\begin{array}{l}-0.051 \\
(0.114)\end{array}$ & $\begin{array}{l}-0.013 \\
(0.058)\end{array}$ & $\begin{array}{c}0.034 \\
(0.055)\end{array}$ & $\begin{array}{l}0.117^{\star *} \\
(0.051)\end{array}$ & $\begin{array}{c}0.124 \\
(0.086)\end{array}$ \\
\hline Applied Arts & $\begin{array}{c}0.018 \\
(0.040)\end{array}$ & $\begin{array}{c}0.011 \\
(0.083)\end{array}$ & $\begin{array}{l}-0.001 \\
(0.056)\end{array}$ & $\begin{array}{c}-0.165^{\star \star \star} \\
(0.052)\end{array}$ & $\begin{array}{c}-0.186^{\star \star \star} \\
(0.022)\end{array}$ & $\begin{array}{c}0.238 \\
(0.161)\end{array}$ & $\begin{array}{c}0.233^{\star \star \star} \\
(0.076)\end{array}$ & $\begin{array}{c}0.267^{\star \star \star} \\
(0.075)\end{array}$ & $\begin{array}{c}0.233^{\star \star \star} \\
(0.066)\end{array}$ & $\begin{array}{c}0.098 \\
(0.120)\end{array}$ \\
\hline Constant & $\begin{array}{c}5.668^{\star \star \star} \\
(0.074) \\
\end{array}$ & $\begin{array}{c}5.699 * \star * \\
(0.056) \\
\end{array}$ & $\begin{array}{c}6.076^{\star \star \star} \\
(0.035) \\
\end{array}$ & $\begin{array}{c}6.401^{\star \star *} \\
(0.035) \\
\end{array}$ & $\begin{array}{c}6.968^{\star \star \star} \\
(0.041) \\
\end{array}$ & $\begin{array}{c}5.661^{\star \star *} \\
(0.092) \\
\end{array}$ & $\begin{array}{c}5.691^{\star \star *} \\
(0.045) \\
\end{array}$ & $\begin{array}{c}5.917^{\star \star \star} \\
(0.041) \\
\end{array}$ & $\begin{array}{l}6.196^{\star \star *} \\
(0.039) \\
\end{array}$ & $\begin{array}{c}6.275^{\star \star \star} \\
(0.064) \\
\end{array}$ \\
\hline $\begin{array}{l}\mathrm{N} \\
\text { Pseudo } \mathrm{R}^{2}\end{array}$ & $\begin{array}{l}4352 \\
0.18\end{array}$ & $\begin{array}{l}4352 \\
0.14 \\
\end{array}$ & $\begin{array}{l}4352 \\
0.18\end{array}$ & $\begin{array}{l}4352 \\
0.12 \\
\end{array}$ & $\begin{array}{l}4352 \\
0.15\end{array}$ & $\begin{array}{l}6027 \\
0.14\end{array}$ & $\begin{array}{l}6027 \\
0.16\end{array}$ & $\begin{array}{l}6027 \\
0.12\end{array}$ & $\begin{array}{l}6027 \\
0.18\end{array}$ & $\begin{array}{l}6027 \\
0.16\end{array}$ \\
\hline
\end{tabular}


Table 6 Wage Returns to Academic Disciplines in Greece, Quantile Regressions, Females, 2002-2003, LFS

\begin{tabular}{|c|c|c|c|c|c|c|c|c|}
\hline & \multicolumn{4}{|c|}{ Public } & \multicolumn{4}{|c|}{ Private } \\
\hline & $\begin{array}{c}(1) \\
0.25\end{array}$ & $\begin{array}{l}(2) \\
0.5\end{array}$ & $\begin{array}{c}(3) \\
0.75\end{array}$ & $\begin{array}{l}(4) \\
0.9\end{array}$ & $\begin{array}{c}(1) \\
0.25\end{array}$ & $\begin{array}{l}(2) \\
0.5\end{array}$ & $\begin{array}{c}(3) \\
0.75\end{array}$ & $\begin{array}{l}(4) \\
0.9\end{array}$ \\
\hline AEI & $\begin{array}{c}0.157^{* * *} \\
(0.012)\end{array}$ & $\begin{array}{l}0.215^{\star \star \star} \\
(0.007)\end{array}$ & $\begin{array}{l}0.134^{\star \star \star} \\
(0.007)\end{array}$ & $\begin{array}{c}0.336^{\star \star \star} \\
(0.084)\end{array}$ & $\begin{array}{c}0.057^{\star * *} \\
(0.003)\end{array}$ & $\begin{array}{c}0.280 * * * \\
(0.018)\end{array}$ & $\begin{array}{c}0.185^{\star * \star} \\
(0.013)\end{array}$ & $\begin{array}{c}0.289 * * * \\
(0.007) \\
\end{array}$ \\
\hline Polytechnics & $\begin{array}{c}0.297^{\star * \star} \\
(0.023)\end{array}$ & $\begin{array}{l}0.274^{\star \star \star} \\
(0.026)\end{array}$ & $\begin{array}{l}0.130 * \star * \\
(0.013)\end{array}$ & $\begin{array}{c}0.145^{\star \star \star} \\
(0.016)\end{array}$ & $\begin{array}{l}0.148^{\star * \star} \\
(0.026)\end{array}$ & $\begin{array}{c}0.372^{\star \star \star} \\
(0.061)\end{array}$ & $\begin{array}{l}0.351^{\star \star \star} \\
(0.046)\end{array}$ & $\begin{array}{c}0.452^{\star \star \star} \\
(0.036)\end{array}$ \\
\hline Science & $\begin{array}{l}0.271^{\star \star \star} \\
(0.084)\end{array}$ & $\begin{array}{l}0.243^{\star \star} \\
(0.096)\end{array}$ & $\begin{array}{l}0.127^{\star \star} \\
(0.050)\end{array}$ & $\begin{array}{c}0.082^{\star \star \star} \\
(0.022)\end{array}$ & $\begin{array}{l}0.434^{\star \star \star} \\
(0.053)\end{array}$ & $\begin{array}{c}0.437^{\star \star \star} \\
(0.132)\end{array}$ & $\begin{array}{c}0.350 * * * \\
(0.095)\end{array}$ & $\begin{array}{c}0.289 * \star \star \\
(0.084)\end{array}$ \\
\hline Science & $\begin{array}{c}0.142^{\star \star \star} \\
(0.034)\end{array}$ & $\begin{array}{l}0.183^{\star \star \star} \\
(0.038)\end{array}$ & $\begin{array}{l}0.067^{\star \star \star} \\
(0.020)\end{array}$ & $\begin{array}{c}0.066^{\star \star \star} \\
(0.022)\end{array}$ & $\begin{array}{l}0.401^{\star \star \star} \\
(0.044)\end{array}$ & $\begin{array}{l}0.351^{\star * \star} \\
(0.104)\end{array}$ & $\begin{array}{l}0.206 * \star \star \\
(0.071)\end{array}$ & $\begin{array}{c}0.279 * \star \star \\
(0.052)\end{array}$ \\
\hline $\begin{array}{l}\text { Physics \& } \\
\text { Maths }\end{array}$ & $\begin{array}{c}0.223^{\star * *} \\
(0.021)\end{array}$ & $\begin{array}{c}0.225^{\star \star \star} \\
(0.023)\end{array}$ & $\begin{array}{c}0.082^{\star \star *} \\
(0.012)\end{array}$ & $\begin{array}{c}0.057^{\star \star \star} \\
(0.013)\end{array}$ & $\begin{array}{l}0.376^{\star \star \star} \\
(0.021)\end{array}$ & $\begin{array}{c}0.318^{\star \star \star} \\
(0.049)\end{array}$ & $\begin{array}{l}0.204^{\star \star \star} \\
(0.037)\end{array}$ & $\begin{array}{c}0.239 \star \star \star \\
(0.030)\end{array}$ \\
\hline Medicine & $\begin{array}{l}0.289 * \star * \\
(0.021)\end{array}$ & $\begin{array}{l}0.369 * * * \\
(0.024)\end{array}$ & $\begin{array}{l}0.277^{\star \star *} \\
(0.012)\end{array}$ & $\begin{array}{l}0.320 * * * \\
(0.015)\end{array}$ & $\begin{array}{l}0.421^{\star \star \star} \\
(0.038)\end{array}$ & $\begin{array}{l}0.476^{\star * *} \\
(0.087)\end{array}$ & $\begin{array}{l}0.394^{* * *} \\
(0.063)\end{array}$ & $\begin{array}{c}0.463^{\star * *} \\
(0.050)\end{array}$ \\
\hline Law & $\begin{array}{c}0.293^{\star \star *} \\
(0.026)\end{array}$ & $\begin{array}{l}0.295^{\star \star \star} \\
(0.030)\end{array}$ & $\begin{array}{c}0.245^{\star \star \star} \\
(0.015)\end{array}$ & $\begin{array}{c}0.220 * * * \\
(0.019)\end{array}$ & $\begin{array}{c}0.070 \star \star \star \\
(0.023)\end{array}$ & $\begin{array}{c}0.288^{\star \star \star} \\
(0.054)\end{array}$ & $\begin{array}{c}0.306^{\star \star \star} \\
(0.041)\end{array}$ & $\begin{array}{c}0.329 * \star \star \\
(0.030)\end{array}$ \\
\hline $\begin{array}{l}\text { Economics \& } \\
\text { Business }\end{array}$ & $\begin{array}{c}0.072^{\star \star \star} \\
(0.014)\end{array}$ & $\begin{array}{c}0.143^{\star \star \star} \\
(0.016)\end{array}$ & $\begin{array}{c}0.041^{* * *} \\
(0.008)\end{array}$ & $\begin{array}{c}0.068^{\star \star *} \\
(0.010)\end{array}$ & $\begin{array}{c}0.127^{\star \star \star} \\
(0.010)\end{array}$ & $\begin{array}{c}0.243^{\star \star *} \\
(0.025)\end{array}$ & $\begin{array}{c}0.128^{\star \star \star} \\
(0.019)\end{array}$ & $\begin{array}{c}0.242^{\star * *} \\
(0.015)\end{array}$ \\
\hline $\begin{array}{l}\text { Social } \\
\text { Sciences }\end{array}$ & $\begin{array}{c}0.102^{\star * *} \\
(0.036)\end{array}$ & $\begin{array}{c}0.209 * * * \\
(0.041)\end{array}$ & $\begin{array}{c}0.061^{\star \star *} \\
(0.021)\end{array}$ & $\begin{array}{c}0.135^{\star \star \star} \\
(0.025)\end{array}$ & $\begin{array}{c}0.026 \\
(0.032)\end{array}$ & $\begin{array}{c}0.315^{\star \star \star} \\
(0.078)\end{array}$ & $\begin{array}{c}0.334^{\star * \star} \\
(0.058)\end{array}$ & $\begin{array}{c}0.328^{\star * *} \\
(0.048)\end{array}$ \\
\hline Humanities & $0.130 * * *$ & $0.204^{* * *}$ & $0.062^{\star \star \star}$ & $0.066^{\star \star \star}$ & $0.124^{\star \star \star}$ & $0.281^{\star \star *}$ & $0.192^{\star \star \star}$ & $0.269 * * *$ \\
\hline
\end{tabular}




\begin{tabular}{|c|c|c|c|c|c|c|c|c|}
\hline & $(0.014)$ & (0.015) & $(0.008)$ & (0.009) & $(0.013)$ & $(0.032)$ & $(0.024)$ & $(0.019)$ \\
\hline \multirow[t]{2}{*}{ Education } & $0.097^{\star \star \star}$ & $0.173^{\star \star \star}$ & $0.036^{\star \star}$ & $0.041^{\star \star}$ & 0.055 & $0.154^{\star}$ & $0.111^{*}$ & $0.449 * \star \star$ \\
\hline & $(0.029)$ & $(0.033)$ & $(0.017)$ & $(0.020)$ & $(0.035)$ & $(0.082)$ & $(0.062)$ & $(0.044)$ \\
\hline \multirow[t]{2}{*}{ Education } & $0.148^{\star \star \star}$ & $0.214^{\star \star \star}$ & $0.055^{\star \star \star}$ & $0.067^{\star \star \star}$ & $0.059 * \star \star$ & $0.160^{\star \star *}$ & $0.160^{\star \star \star}$ & $0.069^{\star \star}$ \\
\hline & $(0.014)$ & $(0.015)$ & $(0.008)$ & $(0.009)$ & $(0.022)$ & $(0.052)$ & $(0.038)$ & $(0.031)$ \\
\hline \multirow[t]{2}{*}{ TEI } & $0.063^{\star \star \star}$ & $0.119^{\star \star \star}$ & $0.034^{\star \star \star}$ & 0.154 & $0.034^{\star \star \star}$ & $0.177^{\star \star \star}$ & $0.125^{\star \star \star}$ & $0.247^{\star \star \star}$ \\
\hline & $(0.016)$ & $(0.010)$ & $(0.009)$ & $(0.162)$ & $(0.006)$ & $(0.037)$ & $(0.028)$ & $(0.014)$ \\
\hline \multirow[t]{2}{*}{ Polytechnics } & 0.038 & $0.159 * * \star$ & $0.034^{\star *}$ & $0.041^{* *}$ & $0.080^{\star \star \star}$ & $0.200^{\star * *}$ & $0.113^{\star \star}$ & $0.225^{\star \star \star}$ \\
\hline & $(0.029)$ & $(0.033)$ & $(0.016)$ & $(0.021)$ & $(0.030)$ & $(0.070)$ & $(0.053)$ & $(0.039)$ \\
\hline \multirow{3}{*}{$\begin{array}{l}\text { Agricultural } \\
\text { Science }\end{array}$} & & & & & & & & \\
\hline & 0.060 & $0.108^{*}$ & $-0.067^{\star \star}$ & $0.071^{* *}$ & 0.014 & $0.283^{\star \star \star}$ & $0.181^{\star \star}$ & $0.208^{\star \star *}$ \\
\hline & $(0.046)$ & $(0.057)$ & $(0.029)$ & $(0.029)$ & $(0.044)$ & $(0.106)$ & $(0.079)$ & $(0.057)$ \\
\hline \multirow{2}{*}{$\begin{array}{l}\text { Food } \\
\text { Technology }\end{array}$} & -0.076 & -0.075 & 0.024 & $-0.101^{\star \star \star}$ & $0.084^{\star}$ & 0.116 & $0.193^{\star \star}$ & $0.158^{\star \star \star}$ \\
\hline & $(0.058)$ & $(0.112)$ & $(0.034)$ & $(0.025)$ & $(0.044)$ & $(0.110)$ & $(0.079)$ & $(0.058)$ \\
\hline \multirow[t]{2}{*}{ Librarianship } & $-0.263^{\star \star \star}$ & 0.059 & 0.008 & 0.023 & $0.114^{\star \star}$ & 0.014 & -0.146 & $-0.225^{\star \star \star}$ \\
\hline & $(0.065)$ & $(0.084)$ & $(0.038)$ & $(0.019)$ & $(0.051)$ & $(0.207)$ & $(0.091)$ & $(0.043)$ \\
\hline \multirow[t]{2}{*}{$\begin{array}{l}\text { Medical- } \\
\text { related }\end{array}$} & $0.064^{\star \star \star}$ & $0.119 * \star *$ & $0.018^{\star *}$ & 0.013 & $0.077^{\star * \star *}$ & $0.171^{* * *}$ & $0.079 * \star$ & $0.268^{\star \star *}$ \\
\hline & $(0.013)$ & $(0.015)$ & $(0.008)$ & $(0.010)$ & $(0.020)$ & $(0.049)$ & $(0.037)$ & $(0.029)$ \\
\hline \multirow[t]{2}{*}{ Applied Arts } & -0.006 & $0.142^{*}$ & 0.034 & $0.244^{\star \star \star}$ & 0.038 & 0.186 & $0.342^{\star \star *}$ & $0.243^{\star \star \star}$ \\
\hline & $(0.040)$ & $(0.084)$ & $(0.038)$ & $(0.019)$ & $(0.057)$ & $(0.154)$ & $(0.102)$ & $(0.032)$ \\
\hline \multirow[t]{2}{*}{ Constant } & $5.521^{\star \star \star}$ & $5.833^{\star \star \star}$ & $6.397^{\star \star \star}$ & $6.434^{\star \star \star}$ & $5.773^{\star \star \star \star}$ & $5.656^{\star \star \star *}$ & $5.962^{\star \star \star}$ & $6.355^{\star \star \star}$ \\
\hline & $(0.047)$ & $(0.053)$ & $(0.026)$ & $(0.032)$ & $(0.035)$ & $(0.084)$ & $(0.063)$ & $(0.051)$ \\
\hline $\mathrm{N}$ & 3429 & 3429 & 3429 & 3429 & 4073 & 4073 & 4073 & 4073 \\
\hline Pseudo $\mathrm{R}^{2}$ & 0.17 & 0.19 & 0.13 & 0.13 & 0.15 & 0.16 & 0.14 & 0.17 \\
\hline
\end{tabular}


Table 7 (Log) Wage Returns to Academic Disciplines in Greece by Cohort, 2002-2003, LFS

\begin{tabular}{|c|c|c|c|c|c|c|}
\hline & \multicolumn{3}{|c|}{ Males } & \multicolumn{3}{|c|}{ Females } \\
\hline & $\begin{array}{c}(1) \\
1950-1960\end{array}$ & $\begin{array}{c}(2) \\
1960-1970\end{array}$ & $\begin{array}{c}(3) \\
>1970\end{array}$ & $\begin{array}{c}(4) \\
1950-1960\end{array}$ & $\begin{array}{c}(5) \\
1960-1970\end{array}$ & $\begin{array}{c}(6) \\
>1970\end{array}$ \\
\hline AEI & $\begin{array}{c}0.223^{\star \star *} \\
(0.014)\end{array}$ & $\begin{array}{l}0.200^{\star \star \star} \\
(0.013)\end{array}$ & $\begin{array}{c}0.162^{\star \star \star} \\
(0.017)\end{array}$ & $\begin{array}{c}0.291^{\star \star \star} \\
(0.017)\end{array}$ & $\begin{array}{l}0.282^{\star \star \star} \\
(0.014)\end{array}$ & $\begin{array}{c}0.184^{\star \star \star} \\
(0.016)\end{array}$ \\
\hline Polytechnics & $\begin{array}{l}0.283^{\star \star \star} \\
(0.031)\end{array}$ & $\begin{array}{l}0.278 * \star \star \\
(0.031)\end{array}$ & $\begin{array}{l}0.251^{\star \star \star} \\
(0.029)\end{array}$ & $\begin{array}{l}0.371^{\star \star \star} \\
(0.038)\end{array}$ & $\begin{array}{c}0.424^{\star \star \star} \\
(0.032)\end{array}$ & $\begin{array}{l}0.261^{\star \star \star} \\
(0.059)\end{array}$ \\
\hline Computer Science & $\begin{array}{c}0.138^{\star \star \star} \\
(0.018)\end{array}$ & $\begin{array}{c}0.453^{\star \star \star} \\
(0.128)\end{array}$ & $\begin{array}{l}0.379 * * \star \\
(0.038)\end{array}$ & $\begin{array}{c}0.000 \\
(0.000)\end{array}$ & $\begin{array}{c}0.415^{\star \star *} \\
(0.068)\end{array}$ & $\begin{array}{c}0.318^{\star \star \star} \\
(0.096)\end{array}$ \\
\hline Agricultural Science & $\begin{array}{c}0.091 \\
(0.059)\end{array}$ & $\begin{array}{l}0.173^{\star *} \\
(0.069)\end{array}$ & $\begin{array}{c}0.265^{\star \star \star} \\
(0.061)\end{array}$ & $\begin{array}{c}0.069 \\
(0.137)\end{array}$ & $\begin{array}{c}0.255^{\star \star \star} \\
(0.045)\end{array}$ & $\begin{array}{c}0.292^{\star \star \star} \\
(0.066)\end{array}$ \\
\hline Physics \& Maths & $\begin{array}{c}0.175^{\star \star \star} \\
(0.028)\end{array}$ & $\begin{array}{l}0.207^{\star \star \star} \\
(0.032)\end{array}$ & $\begin{array}{c}0.174^{\star \star \star} \\
(0.053)\end{array}$ & $\begin{array}{c}0.258^{\star \star \star} \\
(0.032)\end{array}$ & $\begin{array}{l}0.271^{\star \star \star} \\
(0.039)\end{array}$ & $\begin{array}{c}0.245^{\star \star \star} \\
(0.035)\end{array}$ \\
\hline Medicine & $\begin{array}{c}0.365^{\star \star \star} \\
(0.042)\end{array}$ & $\begin{array}{c}0.418^{\star \star \star} \\
(0.045)\end{array}$ & $\begin{array}{l}0.314^{\star \star \star} \\
(0.056)\end{array}$ & $\begin{array}{c}0.405^{\star \star \star} \\
(0.051)\end{array}$ & $\begin{array}{l}0.463^{\star \star \star} \\
(0.059)\end{array}$ & $\begin{array}{l}0.428^{\star \star \star} \\
(0.048)\end{array}$ \\
\hline Law & $\begin{array}{c}0.383^{\star * *} \\
(0.078)\end{array}$ & $\begin{array}{l}0.271^{\star \star \star} \\
(0.067)\end{array}$ & $\begin{array}{c}0.109 \\
(0.176)\end{array}$ & $\begin{array}{c}0.372^{\star \star \star} \\
(0.046)\end{array}$ & $\begin{array}{c}0.425^{\star \star \star} \\
(0.047)\end{array}$ & $\begin{array}{l}0.108^{*} \\
(0.062)\end{array}$ \\
\hline Economics \& Business & $\begin{array}{l}0.230 \star \star \star \\
(0.026)\end{array}$ & $\begin{array}{l}0.179 \star \star \star \\
(0.024)\end{array}$ & $\begin{array}{c}0.112^{\star * *} \\
(0.026)\end{array}$ & $\begin{array}{c}0.230 * \star \star \\
(0.025)\end{array}$ & $\begin{array}{l}0.210^{\star \star \star} \\
(0.020)\end{array}$ & $\begin{array}{c}0.133^{\star \star \star} \\
(0.021)\end{array}$ \\
\hline Social Sciences & $\begin{array}{c}0.189 * \star * \\
(0.056)\end{array}$ & $\begin{array}{l}0.227^{\star \star \star} \\
(0.044)\end{array}$ & $\begin{array}{l}-0.113 \\
(0.108)\end{array}$ & $\begin{array}{l}0.288^{\star \star \star} \\
(0.098)\end{array}$ & $\begin{array}{l}0.240 * \star \star \\
(0.059)\end{array}$ & $\begin{array}{l}0.214^{\star \star} \\
(0.088)\end{array}$ \\
\hline Humanities & $\begin{array}{c}0.144^{\star \star \star} \\
(0.041)\end{array}$ & $\begin{array}{l}0.069 * * \\
(0.031)\end{array}$ & $\begin{array}{l}0.089 * \\
(0.048)\end{array}$ & $\begin{array}{c}0.269^{\star \star *} \\
(0.025)\end{array}$ & $\begin{array}{c}0.232^{\star \star \star} \\
(0.023)\end{array}$ & $\begin{array}{c}0.181^{\star \star \star} \\
(0.029)\end{array}$ \\
\hline Physical Education & $\begin{array}{c}0.113^{\star \star \star} \\
(0.038)\end{array}$ & $\begin{array}{c}0.115^{\star \star \star} \\
(0.034)\end{array}$ & $\begin{array}{l}-0.004 \\
(0.047)\end{array}$ & $\begin{array}{c}0.210^{\star \star \star} \\
(0.051)\end{array}$ & $\begin{array}{c}0.221^{\star \star *} \\
(0.053)\end{array}$ & $\begin{array}{l}0.123^{*} \\
(0.067)\end{array}$ \\
\hline Education & $0.107^{* \star *}$ & $0.182^{\star \star *}$ & $0.132^{*}$ & $0.204^{\star \star *}$ & $0.287^{\star \star *}$ & $0.185^{\star \star \star}$ \\
\hline
\end{tabular}




\begin{tabular}{|c|c|c|c|c|c|c|}
\hline & $(0.026)$ & $(0.023)$ & $(0.078)$ & $(0.025)$ & $(0.022)$ & $(0.034)$ \\
\hline TEI & $\begin{array}{c}0.150^{\star \star \star} \\
(0.025)\end{array}$ & $\begin{array}{c}0.125^{\star \star \star} \\
(0.021)\end{array}$ & $\begin{array}{c}0.118^{\star * \star} \\
(0.027)\end{array}$ & $\begin{array}{c}0.185^{\star \star \star} \\
(0.028)\end{array}$ & $\begin{array}{c}0.153^{\star \star *} \\
(0.018)\end{array}$ & $\begin{array}{c}0.174^{\star \star \star} \\
(0.027)\end{array}$ \\
\hline Polytechnic & $\begin{array}{c}0.163^{\star \star \star} \\
(0.026)\end{array}$ & $\begin{array}{c}0.131^{\star * \star} \\
(0.027)\end{array}$ & $\begin{array}{c}0.144^{\star * \star} \\
(0.032)\end{array}$ & $\begin{array}{c}0.233^{\star \star \star} \\
(0.043)\end{array}$ & $\begin{array}{c}0.165^{\star \star \star} \\
(0.049)\end{array}$ & $\begin{array}{l}0.113^{*} \\
(0.060)\end{array}$ \\
\hline Agricultural & $\begin{array}{c}0.135 \\
(0.093)\end{array}$ & $\begin{array}{c}0.168^{\star * *} \\
(0.047)\end{array}$ & $\begin{array}{l}-0.018 \\
(0.065)\end{array}$ & $\begin{array}{c}0.328 * \star * \\
(0.042)\end{array}$ & $\begin{array}{c}0.003 \\
(0.079)\end{array}$ & $\begin{array}{c}0.112 \\
(0.131)\end{array}$ \\
\hline Food Technology & $\begin{array}{c}0.138 \\
(0.177)\end{array}$ & $\begin{array}{l}0.141^{\star \star} \\
(0.068)\end{array}$ & $\begin{array}{c}0.038 \\
(0.097)\end{array}$ & $\begin{array}{l}0.149 * \\
(0.088)\end{array}$ & $\begin{array}{c}-0.012 \\
(0.122)\end{array}$ & $\begin{array}{c}0.044 \\
(0.118)\end{array}$ \\
\hline Librarianship & $\begin{array}{c}0.000 \\
(0.000)\end{array}$ & $\begin{array}{c}0.000 \\
(0.000)\end{array}$ & $\begin{array}{c}0.000 \\
(0.000)\end{array}$ & $\begin{array}{c}0.000 \\
(0.000)\end{array}$ & $\begin{array}{l}0.189 * \\
(0.106)\end{array}$ & $\begin{array}{l}-0.120 \\
(0.090)\end{array}$ \\
\hline Medical-related & $\begin{array}{c}0.055 \\
(0.133)\end{array}$ & $\begin{array}{l}0.098^{\star *} \\
(0.041)\end{array}$ & $\begin{array}{c}0.067 \\
(0.077)\end{array}$ & $\begin{array}{c}0.141^{\star \star *} \\
(0.039)\end{array}$ & $\begin{array}{c}0.156^{\star * *} \\
(0.019)\end{array}$ & $\begin{array}{c}0.207^{\star * *} \\
(0.033)\end{array}$ \\
\hline Applied Arts & $\begin{array}{c}-0.011 \\
(0.091)\end{array}$ & $\begin{array}{c}0.130 * \\
(0.068)\end{array}$ & $\begin{array}{c}0.228^{\star * *} \\
(0.057)\end{array}$ & $\begin{array}{l}-0.028 \\
(0.033)\end{array}$ & $\begin{array}{c}0.032 \\
(0.175)\end{array}$ & $\begin{array}{l}0.224^{\star *} \\
(0.095)\end{array}$ \\
\hline Constant & $\begin{array}{c}4.924^{\star \star \star} \\
(1.563)\end{array}$ & $\begin{array}{c}4.294^{\star \star \star} \\
(0.877)\end{array}$ & $\begin{array}{c}5.305^{\star \star \star} \\
(0.340)\end{array}$ & $\begin{array}{c}6.479 * * * \\
(2.046)\end{array}$ & $\begin{array}{c}5.402^{\star \star \star} \\
(1.005)\end{array}$ & $\begin{array}{c}5.378^{\star \star *} \\
(0.425)\end{array}$ \\
\hline $\begin{array}{l}N \\
\mathrm{R}^{2}\end{array}$ & $\begin{array}{l}2724 \\
0.197\end{array}$ & $\begin{array}{l}3181 \\
0.207\end{array}$ & $\begin{array}{l}3172 \\
0.196\end{array}$ & $\begin{array}{l}1769 \\
0.377\end{array}$ & $\begin{array}{l}2769 \\
0.324\end{array}$ & $\begin{array}{l}2482 \\
0.232\end{array}$ \\
\hline
\end{tabular}


Appendix Tables

Table A1 (Log) Wage Returns to Educational Qualifications in Greece, 2002-2003, LFS

\begin{tabular}{|c|c|c|c|c|c|c|c|c|}
\hline & \multicolumn{4}{|c|}{ Males } & \multicolumn{4}{|c|}{ Females } \\
\hline & $\begin{array}{l}(1) \\
\text { All }\end{array}$ & $\begin{array}{l}(2) \\
\text { Full-time } \\
\text { Perm }\end{array}$ & $\begin{array}{c}\text { (3) } \\
\text { Public }\end{array}$ & $\begin{array}{c}\text { (4) } \\
\text { Private }\end{array}$ & $\begin{array}{l}\text { (5) } \\
\text { All }\end{array}$ & $\begin{array}{l}\text { (6) } \\
\text { Full-time } \\
\text { Perm }\end{array}$ & $\begin{array}{c}\text { (7) } \\
\text { Public }\end{array}$ & $\begin{array}{c}\text { (8) } \\
\text { Private }\end{array}$ \\
\hline \multicolumn{9}{|l|}{ Qualifications } \\
\hline PhD & $\begin{array}{l}0.401^{\star \star \star} \\
(0.039)\end{array}$ & $\begin{array}{l}0.425^{\star \star \star} \\
(0.037)\end{array}$ & $\begin{array}{l}0.364^{\star \star \star} \\
(0.043)\end{array}$ & $\begin{array}{l}0.240 * \star \star \\
(0.069)\end{array}$ & $\begin{array}{l}0.414^{\star \star \star} \\
(0.057)\end{array}$ & $\begin{array}{l}0.441^{\star \star \star} \\
(0.054)\end{array}$ & $\begin{array}{l}0.334^{\star * *} \\
(0.056)\end{array}$ & $\begin{array}{l}0.219 * \\
(0.125)\end{array}$ \\
\hline Masters & $\begin{array}{l}0.332^{\star \star \star} \\
(0.038)\end{array}$ & $\begin{array}{l}0.343^{\star \star \star} \\
(0.039)\end{array}$ & $\begin{array}{l}0.323^{\star \star \star} \\
(0.053)\end{array}$ & $\begin{array}{l}0.312^{\star \star \star} \\
(0.052)\end{array}$ & $\begin{array}{l}0.382^{\star \star \star} \\
(0.038)\end{array}$ & $\begin{array}{l}0.406^{\star \star \star} \\
(0.038)\end{array}$ & $\begin{array}{l}0.292^{\star \star \star} \\
(0.044)\end{array}$ & $\begin{array}{l}0.416^{\star \star *} \\
(0.068)\end{array}$ \\
\hline $\mathrm{AEI}$ & $\begin{array}{l}0.216^{\star \star \star} \\
(0.008)\end{array}$ & $\begin{array}{l}0.218^{\star \star \star} \\
(0.008)\end{array}$ & $\begin{array}{l}0.159 \star \star \star \\
(0.010)\end{array}$ & $\begin{array}{l}0.236^{\star \star \star} \\
(0.013)\end{array}$ & $\begin{array}{l}0.255^{\star \star \star} \\
(0.008)\end{array}$ & $\begin{array}{l}0.259 \star \star \star \\
(0.009)\end{array}$ & $\begin{array}{l}0.206^{\star \star \star} \\
(0.012)\end{array}$ & $\begin{array}{l}0.224^{\star \star \star} \\
(0.013)\end{array}$ \\
\hline TEI & $\begin{array}{l}0.132^{\star * \star} \\
(0.013)\end{array}$ & $\begin{array}{l}0.136^{\star \star *} \\
(0.013)\end{array}$ & $\begin{array}{l}0.080 * \star \star \\
(0.016)\end{array}$ & $\begin{array}{l}0.151^{\star \star \star} \\
(0.020)\end{array}$ & $\begin{array}{l}0.162^{\star \star \star} \\
(0.013)\end{array}$ & $\begin{array}{l}0.166^{\star \star \star} \\
(0.013)\end{array}$ & $\begin{array}{l}0.076 * \star \star \\
(0.015)\end{array}$ & $\begin{array}{l}0.148^{\star \star \star} \\
(0.028)\end{array}$ \\
\hline $\begin{array}{l}\text { Post-secondary } \\
\text { (IEK/Colleges) }\end{array}$ & $\begin{array}{l}0.066^{\star \star \star} \\
(0.011)\end{array}$ & $\begin{array}{c}0.068^{\star \star \star} \\
(0.011)\end{array}$ & $\begin{array}{c}0.015 \\
(0.016)\end{array}$ & $\begin{array}{l}0.085^{\star \star \star} \\
(0.013)\end{array}$ & $\begin{array}{l}0.055^{\star \star \star} \\
(0.010)\end{array}$ & $\begin{array}{l}0.056^{\star * \star} \\
(0.011)\end{array}$ & $\begin{array}{l}0.057^{\star \star *} \\
(0.017)\end{array}$ & $\begin{array}{l}0.047^{\star \star \star} \\
(0.012)\end{array}$ \\
\hline $\begin{array}{l}\text { Other (e.g. military } \\
\text { schools) }\end{array}$ & $\begin{array}{l}0.207^{\star \star \star} \\
(0.012)\end{array}$ & $\begin{array}{l}0.199 * \star \star \\
(0.012)\end{array}$ & $\begin{array}{l}0.141^{\star * \star} \\
(0.013)\end{array}$ & $\begin{array}{l}0.193^{\star \star \star} \\
(0.068)\end{array}$ & $\begin{array}{l}0.269 * * \star \\
(0.035)\end{array}$ & $\begin{array}{l}0.258^{\star \star \star} \\
(0.036)\end{array}$ & $\begin{array}{l}0.180 \star \star \star \\
(0.035)\end{array}$ & $\begin{array}{l}-0.012 \\
(0.131)\end{array}$ \\
\hline Primary & $\begin{array}{c}-0.101^{\star \star \star} \\
(0.007)\end{array}$ & $\begin{array}{c}-0.102^{\star \star \star} \\
(0.007)\end{array}$ & $\begin{array}{c}-0.121^{\star \star \star} \\
(0.012)\end{array}$ & $\begin{array}{c}-0.070^{\star \star \star} \\
(0.009)\end{array}$ & $\begin{array}{c}-0.156^{\star \star \star} \\
(0.011)\end{array}$ & $\begin{array}{c}-0.165^{\star \star \star} \\
(0.012)\end{array}$ & $\begin{array}{c}-0.248^{\star \star \star} \\
(0.019)\end{array}$ & $\begin{array}{c}-0.098 * * * \\
(0.013)\end{array}$ \\
\hline Age Group & & & & & & & & \\
\hline $25-34$ & $\begin{array}{c}0.048^{\star \star \star} \\
(0.012)\end{array}$ & $\begin{array}{c}0.021 \\
(0.013)\end{array}$ & $\begin{array}{l}0.046 * \star \\
(0.023)\end{array}$ & $\begin{array}{c}0.044^{\star \star \star} \\
(0.013)\end{array}$ & $\begin{array}{c}0.064^{\star \star \star} \\
(0.013)\end{array}$ & $\begin{array}{c}0.045^{\star \star \star} \\
(0.014)\end{array}$ & $\begin{array}{c}0.118^{\star \star \star} \\
(0.034)\end{array}$ & $\begin{array}{c}0.055^{\star \star \star} \\
(0.014)\end{array}$ \\
\hline $35-44$ & $0.085^{\star \star \star}$ & $0.054^{\star \star \star}$ & 0.039 & $0.098^{\star \star \star}$ & $0.090 * \star \star$ & $0.062^{\star \star \star}$ & $0.116^{\star \star *}$ & $0.064^{\star \star \star}$ \\
\hline
\end{tabular}




\begin{tabular}{|c|c|c|c|c|c|c|c|c|}
\hline & $(0.016)$ & $(0.017)$ & (0.028) & (0.019) & $(0.017)$ & (0.019) & $(0.038)$ & (0.021) \\
\hline \multirow[t]{2}{*}{$45-54$} & $0.106^{\star \star \star}$ & 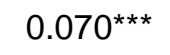 & 0.036 & $0.139 * \star \star$ & $0.093^{\star \star \star}$ & $0.063^{\star * *}$ & $0.123^{\star \star \star}$ & $0.060^{\star \star}$ \\
\hline & $(0.019)$ & $(0.020)$ & $(0.031)$ & $(0.024)$ & $(0.021)$ & $(0.023)$ & $(0.040)$ & $(0.029)$ \\
\hline \multirow[t]{2}{*}{$55-64$} & $0.106^{\star \star \star}$ & $0.072^{\star \star \star}$ & 0.057 & $0.121^{\star \star \star}$ & $0.093^{\star \star \star}$ & $0.072^{\star \star}$ & $0.139 * \star \star$ & 0.045 \\
\hline & $(0.022)$ & $(0.023)$ & $(0.036)$ & $(0.030)$ & $(0.028)$ & $(0.030)$ & $(0.046)$ & $(0.042)$ \\
\hline \multirow[t]{2}{*}{ Married } & $0.060^{\star \star \star}$ & $0.060^{\star \star \star}$ & $0.052^{\star \star \star}$ & $0.066^{\star \star \star}$ & $0.055^{\star \star \star}$ & $0.057^{\star \star \star}$ & $0.061^{\star \star \star}$ & $0.042^{\star \star *}$ \\
\hline & $(0.008)$ & (0.008) & $(0.011)$ & $(0.011)$ & $(0.009)$ & $(0.009)$ & $(0.013)$ & $(0.011)$ \\
\hline \multirow[t]{2}{*}{ Head Household } & $0.056^{\star \star \star}$ & $0.052^{\star \star \star}$ & $0.052^{\star \star \star}$ & $0.046^{\star \star \star}$ & $0.053^{\star \star \star}$ & $0.052^{\star \star \star}$ & $0.043^{\star \star \star}$ & $0.056^{\star \star \star}$ \\
\hline & $(0.009)$ & $(0.009)$ & $(0.012)$ & $(0.012)$ & $(0.010)$ & $(0.011)$ & $(0.015)$ & $(0.013)$ \\
\hline \multirow[t]{2}{*}{ Tenure } & $0.015^{\star \star \star}$ & $0.015^{\star \star \star}$ & $0.017^{\star \star \star}$ & $0.012^{\star \star \star}$ & $0.019 * \star \star$ & $0.018^{\star \star \star}$ & $0.021^{\star \star \star}$ & $0.015^{\star \star \star}$ \\
\hline & $(0.001)$ & $(0.001)$ & $(0.002)$ & $(0.001)$ & $(0.001)$ & $(0.001)$ & $(0.002)$ & $(0.002)$ \\
\hline \multirow[t]{2}{*}{ Tenure sq } & $-0.000^{* * *}$ & -0.000 *** & $-0.000^{* * *}$ & -0.000 *** & -0.000 *** & $-0.000^{\star \star *}$ & -0.000 *** & $-0.000^{* *}$ \\
\hline & $(0.000)$ & $(0.000)$ & $(0.000)$ & $(0.000)$ & $(0.000)$ & $(0.000)$ & $(0.000)$ & $(0.000)$ \\
\hline \multirow[t]{2}{*}{ Full time } & $0.289^{\star \star \star}$ & & $0.305^{\star \star \star}$ & 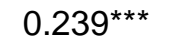 & $0.397^{\star \star \star}$ & & $0.372^{\star \star \star}$ & $0.315^{\star \star \star}$ \\
\hline & $(0.029)$ & & $(0.071)$ & $(0.032)$ & $(0.020)$ & & $(0.039)$ & $(0.025)$ \\
\hline \multirow{2}{*}{$\begin{array}{l}\text { Usual Weekly } \\
\text { Hours }\end{array}$} & $0,005 * \star *$ & 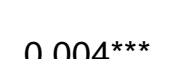 & $0.004^{\star \star \star}$ & $0,006 * \star *$ & $0002 * \star *$ & 0001 ** & $0.004^{\star * *}$ & $0.005^{\star \star \star}$ \\
\hline & $(0.000)$ & $(0.000)$ & $(0.001)$ & $(0.001)$ & $(0.001)$ & $(0.001)$ & $(0.001)$ & $(0.001)$ \\
\hline \multirow[t]{2}{*}{ Constant } & $5.932^{\star \star \star}$ & $6.273^{\star \star \star}$ & $6.005^{\star \star \star}$ & $5.897^{\star \star \star}$ & $5.805^{\star \star \star}$ & $6.252^{\star \star \star}$ & $5.798^{\star \star \star}$ & $5.791^{\star \star *}$ \\
\hline & $(0.036)$ & $(0.029)$ & $(0.079)$ & $(0.043)$ & $(0.032)$ & $(0.038)$ & $(0.060)$ & $(0.043)$ \\
\hline $\mathrm{N}$ & 15659 & 14125 & 6167 & 9492 & 10519 & 8915 & 4296 & 6223 \\
\hline $\mathrm{R}^{2}$ & 0.287 & 0.259 & 0.267 & 0.245 & 0.380 & 0.323 & 0.397 & 0.258 \\
\hline
\end{tabular}


Table A2 (Log) Wage Returns to Academic Disciplines in Greece, 2002-2003, LFS

\begin{tabular}{|c|c|c|c|c|}
\hline & \multicolumn{2}{|c|}{ Males } & \multicolumn{2}{|c|}{ Females } \\
\hline & $\begin{array}{l}(1) \\
\text { All }\end{array}$ & $\begin{array}{c}\text { (2) } \\
\text { Full-time } \\
\text { Permanent }\end{array}$ & $\begin{array}{l}(3) \\
\text { All }\end{array}$ & $\begin{array}{c}\text { (4) } \\
\text { Full-time } \\
\text { Permanent }\end{array}$ \\
\hline AEI & & & & \\
\hline Polytechnics & $\begin{array}{c}0.269 * \star * \\
(0.016)\end{array}$ & $\begin{array}{c}0.271^{\star * *} \\
(0.016)\end{array}$ & $\begin{array}{c}0.352^{\star \star \star} \\
(0.025)\end{array}$ & $\begin{array}{c}0.343^{\star \star \star} \\
(0.026)\end{array}$ \\
\hline Computer Science & $\begin{array}{c}0.420 * * * \\
(0.047)\end{array}$ & $\begin{array}{c}0.434^{\star * *} \\
(0.050)\end{array}$ & $\begin{array}{c}0.368^{\star \star \star} \\
(0.066)\end{array}$ & $\begin{array}{c}0.287^{\star \star \star} \\
(0.060)\end{array}$ \\
\hline Agricultural Science & $\begin{array}{c}0.146^{\star * *} \\
(0.030)\end{array}$ & $\begin{array}{c}0.137^{\star * *} \\
(0.031)\end{array}$ & $\begin{array}{c}0.242^{\star * *} \\
(0.038)\end{array}$ & $\begin{array}{c}0.266^{\star \star \star} \\
(0.038)\end{array}$ \\
\hline Physics \& Maths & $\begin{array}{c}0.184^{\star * *} \\
(0.016)\end{array}$ & $\begin{array}{c}0.182^{\star \star *} \\
(0.016)\end{array}$ & $\begin{array}{c}0.264^{\star * *} \\
(0.020)\end{array}$ & $\begin{array}{c}0.263^{\star * *} \\
(0.022)\end{array}$ \\
\hline Medicine & $\begin{array}{c}0.385^{\star * \star} \\
(0.023)\end{array}$ & $\begin{array}{c}0.387^{\star * \star} \\
(0.024)\end{array}$ & $\begin{array}{c}0.436 * \star \star \\
(0.026)\end{array}$ & $\begin{array}{c}0.430 * * \star \\
(0.027)\end{array}$ \\
\hline Law & $\begin{array}{c}0.308^{\star \star \star} \\
(0.045)\end{array}$ & $\begin{array}{c}0.328^{\star * *} \\
(0.043)\end{array}$ & $\begin{array}{c}0.296 * \star \star \\
(0.031)\end{array}$ & $\begin{array}{c}0.338^{\star \star \star} \\
(0.029)\end{array}$ \\
\hline Economics \& Business & $\begin{array}{c}0.194^{\star \star \star} \\
(0.014)\end{array}$ & $\begin{array}{c}0.208^{\star * \star} \\
(0.014)\end{array}$ & $\begin{array}{c}0.186^{\star \star \star} \\
(0.012)\end{array}$ & $\begin{array}{c}0.195^{\star \star \star} \\
(0.012)\end{array}$ \\
\hline Social Sciences & $\begin{array}{c}0.213^{\star * *} \\
(0.039)\end{array}$ & $\begin{array}{c}0.219 * * * \\
(0.041)\end{array}$ & $\begin{array}{c}0.249 * \star \star \\
(0.043)\end{array}$ & $\begin{array}{c}0.272^{\star \star \star} \\
(0.042)\end{array}$ \\
\hline Humanities & $\begin{array}{c}0.109 * * * \\
(0.020)\end{array}$ & $\begin{array}{c}0.124^{\star \star \star} \\
(0.020)\end{array}$ & $\begin{array}{c}0.229 * * \star \\
(0.014)\end{array}$ & $\begin{array}{c}0.222^{\star \star \star} \\
(0.015)\end{array}$ \\
\hline Physical Education & $\begin{array}{c}0.111^{\star \star \star} \\
(0.023)\end{array}$ & $\begin{array}{c}0.107^{\star \star \star} \\
(0.023)\end{array}$ & $\begin{array}{c}0.188^{\star \star \star} \\
(0.035)\end{array}$ & $\begin{array}{c}0.248^{\star \star \star} \\
(0.035)\end{array}$ \\
\hline Education & $\begin{array}{c}0.156^{\star \star \star} \\
(0.016)\end{array}$ & $\begin{array}{c}0.152^{\star \star \star} \\
(0.016)\end{array}$ & $\begin{array}{c}0.241^{\star \star \star} \\
(0.014)\end{array}$ & $\begin{array}{c}0.240 * \star \star \\
(0.014)\end{array}$ \\
\hline TEI & & & & \\
\hline Polytechnics & $\begin{array}{c}0.143^{\star \star \star} \\
(0.015)\end{array}$ & $\begin{array}{c}0.146^{\star \star \star} \\
(0.015)\end{array}$ & $\begin{array}{c}0.159 * * \star \\
(0.030)\end{array}$ & $\begin{array}{c}0.177^{\star \star \star} \\
(0.032)\end{array}$ \\
\hline Agricultural Science & $\begin{array}{l}0.071^{*} \\
(0.040)\end{array}$ & $\begin{array}{l}0.073^{*} \\
(0.040)\end{array}$ & $\begin{array}{l}0.120 \star * \\
(0.056)\end{array}$ & $\begin{array}{c}0.098^{*} \\
(0.059)\end{array}$ \\
\hline Food Technology & $\begin{array}{c}0.113 \\
(0.080)\end{array}$ & $\begin{array}{c}0.114 \\
(0.081)\end{array}$ & $\begin{array}{c}0.041 \\
(0.073)\end{array}$ & $\begin{array}{c}0.085 \\
(0.070)\end{array}$ \\
\hline Librarianship & $\begin{array}{c}0.000 \\
(0.000)\end{array}$ & $\begin{array}{c}0.000 \\
(0.000)\end{array}$ & $\begin{array}{c}0.101 \\
(0.085)\end{array}$ & $\begin{array}{c}0.184^{\star \star \star} \\
(0.071)\end{array}$ \\
\hline Medical-related & $\begin{array}{l}0.092^{\star *} \\
(0.038)\end{array}$ & $\begin{array}{c}0.103^{\star * \star} \\
(0.039)\end{array}$ & $\begin{array}{c}0.167^{\star * \star} \\
(0.015)\end{array}$ & $\begin{array}{c}0.167^{\star \star \star} \\
(0.015)\end{array}$ \\
\hline Applied Arts & $\begin{array}{l}0.131^{\star *} \\
(0.051)\end{array}$ & $\begin{array}{c}0.130 \star \star \star \\
(0.050)\end{array}$ & $\begin{array}{c}0.196 * \star \star \\
(0.074)\end{array}$ & $\begin{array}{c}0.209 * \star \star \\
(0.076)\end{array}$ \\
\hline Constant & $\begin{array}{c}5.988^{\star * *} \\
(0.045) \\
\end{array}$ & $\begin{array}{c}6.338^{\star \star \star} \\
(0.035) \\
\end{array}$ & $\begin{array}{c}5.828^{\star * \star} \\
(0.041)\end{array}$ & $\begin{array}{c}6.308^{\star \star \star} \\
(0.047)\end{array}$ \\
\hline $\begin{array}{l}\mathrm{N} \\
\mathrm{R}^{2}\end{array}$ & $\begin{array}{c}10379 \\
0.312\end{array}$ & $\begin{array}{l}9452 \\
0.285\end{array}$ & $\begin{array}{l}7502 \\
0.385\end{array}$ & $\begin{array}{l}6522 \\
0.339\end{array}$ \\
\hline
\end{tabular}

Notes: Robust standard errors in parentheses; ${ }^{\star \star \star} p<0.01,{ }^{\star \star} p<0.05,{ }^{\star} p<0.1$. All returns are measured relative to a "Secondary" degree. The remaining regression output is available from the authors upon request. 


\section{Appendix 1: Correcting for selectivity bias in OLS estimates}

As discussed in the main text, in order to correct the OLS estimates of equation (1) for potential selectivity bias, a maximum likelihood technique based on a two-equation system is also employed in the analysis. In the first-step, a selection equation into paid employment, $E$, for each individual $i$, conditional on his/her qualification or type of degree, $S_{i j}$, is estimated as follows:

$$
E_{i}^{*}=\sum_{j=1}^{J} S_{i j} \delta_{j}+\mathbf{Z} \gamma+u_{i}
$$

where $\mathbf{Z}$ is a vector of observable variables that include at least one identifying exogenous variable that is orthogonal to the wage determination process, $\gamma$ and $\delta$ are vectors of regression parameters and $u$ is the random error term. From equation (A1) it is calculated that the realization of participation into paid employment occurs with probability $\Phi\left(\sum_{j=1}^{J} S_{i j} \delta_{j}+\mathbf{Z} \gamma\right)$ whenever $P_{i}^{*}>0$ and probability 1- $\Phi($ $\sum_{j=1}^{J} S_{i j} \delta_{j}+\mathbf{Z} \gamma$ ) when $P_{i}^{*} \leq 0$, where $\Phi$ is the standard normal distribution function. An important distinction is that the selection equation (A1) is estimated for the female sample using the population of inactive women as the reference category, whilst the control group for the sub-sample of men refers to those who select self-employment. Conditional on these derived probabilities, the main wage equation (1) is subsequently estimated in the second stage. Correlation between the random error terms of the two equations, $\operatorname{Corr}(\varepsilon, u)=\rho$, is then indicative of the presence of selectivity bias that will lead to biased estimates of the determinants in the wage equation.

The estimates of the first-stage employment equation are shown in Table A3 below. In order to identify this equation, an additional variable is used that captures the number of children in the household (Mroz, 1987), which is confirmed to be an insignificant determinant of female wages. Interestingly, it is found that female workers are more likely to be inactive when there are more than four children in the household. This finding potentially reflects the fact that, according to Greek law, families with more than four children are officially acknowledged as "multiple child bearers". This 
entails certain privileges and benefits paid by the Greek state, which are likely to manifest in an increase of the reservation wages of women. Based on estimates of this procedure, no evidence of selectivity bias due to female participation is found $\left(\mathrm{H}_{0}: \rho=0 ; \chi^{2}(1)=0.54 ; p=0.46\right)$, so the coefficients do not differ significantly in Table A3 from those in Table 3.

A similar estimation technique is employed to correct the male OLS coefficients for the omission of the self-employed from the analysis. Identification of the individual choice of salaried employment relative to self-employment is achieved via a variable which separates the respondents according to whether they work from home. Indeed, it is confirmed that home-working is more prevalent amongst self-employed workers, and is independent of wages (see Table A3). Moreover, no evidence of selectivity bias is found when the aggregate educational qualifications are used as controls $\left(\mathrm{H}_{0}: \rho=0\right.$; $\chi^{2}(1)=0.41 ; p=0.52$ ), yet there is evidence of such bias when the detailed fields of study are employed in the estimation instead $\left(\mathrm{H}_{0}: \rho=0 ; \chi^{2}(1)=3.58 ; p=0.059\right)$ (see Table A4). 
Table A3 Two-step ML estimates of Returns to Educational Qualifications in Greece, 2002-2003, LFS

\begin{tabular}{|c|c|c|c|c|}
\hline & \multicolumn{2}{|c|}{ Males } & \multicolumn{2}{|c|}{ Females } \\
\hline & (1) & $\begin{array}{c}(2) \\
\text { Selection } \\
\text { (Employee } \\
\text { vs. Self- } \\
\text { employ) } \\
\end{array}$ & $\begin{array}{c}\text { (3) } \\
\text { Log(Wage) } \\
\end{array}$ & $\begin{array}{c}\text { (4) } \\
\text { Selection } \\
\text { (Employee } \\
\text { vs. inactive) }\end{array}$ \\
\hline Qualification & & & & \\
\hline PhD & $\begin{array}{l}0.401^{* * *} \\
(0.039)\end{array}$ & $\begin{array}{l}0.440 \star * \\
(0.203)\end{array}$ & $\begin{array}{c}0.400^{\star \star *} \\
(0.057)\end{array}$ & $\begin{array}{c}1.320 * \star * \\
(0.281)\end{array}$ \\
\hline Masters & $\begin{array}{l}0.331^{\star \star \star} \\
(0.038)\end{array}$ & $\begin{array}{l}-0.149 \\
(0.120)\end{array}$ & $\begin{array}{c}0.373^{\star \star \star} \\
(0.038)\end{array}$ & $\begin{array}{l}0.796^{\star \star \star} \\
(0.145)\end{array}$ \\
\hline AEI & $\begin{array}{l}0.215^{\star \star \star} \\
(0.008)\end{array}$ & $\begin{array}{c}-0.103^{\star \star \star} \\
(0.025)\end{array}$ & $\begin{array}{l}0.245^{\star \star \star} \\
(0.010)\end{array}$ & $\begin{array}{l}0.864^{\star \star \star} \\
(0.024)\end{array}$ \\
\hline TEl & $\begin{array}{c}0.132^{\star \star \star} \\
(0.013)\end{array}$ & $\begin{array}{l}0.098^{\star \star} \\
(0.050)\end{array}$ & $\begin{array}{c}0.151^{\star \star \star} \\
(0.014)\end{array}$ & $\begin{array}{c}0.915^{\star \star \star} \\
(0.048)\end{array}$ \\
\hline $\begin{array}{l}\text { Post-secondary } \\
\text { (IEK/Colleges) }\end{array}$ & $\begin{array}{c}0.066^{\star \star \star} \\
(0.011)\end{array}$ & $\begin{array}{l}0.099 * \star \star \\
(0.033)\end{array}$ & $\begin{array}{c}0.050^{\star \star \star} \\
(0.010)\end{array}$ & $\begin{array}{c}0.394^{\star \star \star} \\
(0.028)\end{array}$ \\
\hline $\begin{array}{l}\text { Other (e.g. } \\
\text { military schools) }\end{array}$ & $\begin{array}{l}0.211^{\star \star \star} \\
(0.013)\end{array}$ & $\begin{array}{c}0.816^{\star \star \star} \\
(0.074)\end{array}$ & $\begin{array}{l}0.261^{\star \star \star} \\
(0.035)\end{array}$ & $\begin{array}{c}0.640 * \star \star \\
(0.150)\end{array}$ \\
\hline Primary & $\begin{array}{c}-0.103^{\star \star *} \\
(0.007)\end{array}$ & $\begin{array}{c}-0.208^{\star \star \star} \\
(0.020)\end{array}$ & $\begin{array}{c}-0.151^{\star \star *} \\
(0.011)\end{array}$ & $\begin{array}{c}-0.327^{\star * *} \\
(0.021)\end{array}$ \\
\hline Age Group & & & & \\
\hline $25-34$ & $\begin{array}{c}0.049^{\star \star \star} \\
(0.012)\end{array}$ & $\begin{array}{c}0.010 \\
(0.035)\end{array}$ & $\begin{array}{c}0.062^{\star \star \star} \\
(0.013)\end{array}$ & $\begin{array}{c}0.134^{\star \star \star} \\
(0.033)\end{array}$ \\
\hline $35-44$ & $\begin{array}{l}0.086^{\star \star \star} \\
(0.016)\end{array}$ & $\begin{array}{c}0.031 \\
(0.049)\end{array}$ & $\begin{array}{l}0.087^{\star \star \star} \\
(0.017)\end{array}$ & $\begin{array}{l}0.199^{\star \star \star} \\
(0.047)\end{array}$ \\
\hline $45-54$ & $\begin{array}{l}0.106^{\star \star *} \\
(0.019)\end{array}$ & $\begin{array}{c}0.067 \\
(0.059)\end{array}$ & $\begin{array}{l}0.092^{\star \star \star} \\
(0.021)\end{array}$ & $\begin{array}{c}0.082 \\
(0.057)\end{array}$ \\
\hline $55-64$ & $\begin{array}{l}0.104^{\star \star \star} \\
(0.023)\end{array}$ & $\begin{array}{c}-0.201^{\star \star \star} \\
(0.069)\end{array}$ & $\begin{array}{l}0.102^{\star \star \star} \\
(0.029)\end{array}$ & $\begin{array}{c}-0.575^{\star \star \star} \\
(0.070)\end{array}$ \\
\hline Married & $\begin{array}{l}0.060^{\star \star \star} \\
(0.008)\end{array}$ & $\begin{array}{c}0.016 \\
(0.026)\end{array}$ & $\begin{array}{l}0.059^{\star \star \star} \\
(0.009)\end{array}$ & $\begin{array}{c}-0.338^{\star \star *} \\
(0.024)\end{array}$ \\
\hline $\begin{array}{l}\text { Head of } \\
\text { Household }\end{array}$ & $\begin{array}{c}0.057^{\star \star *} \\
(0.009)\end{array}$ & $\begin{array}{c}0.139 * \star \star \\
(0.028)\end{array}$ & $\begin{array}{c}0.051^{\star \star \star} \\
(0.010)\end{array}$ & $\begin{array}{c}0.176^{\star \star \star} \\
(0.030)\end{array}$ \\
\hline Tenure & $\begin{array}{l}0.015^{\star \star \star} \\
(0.001)\end{array}$ & $\begin{array}{c}-0.025^{\star \star \star} \\
(0.003)\end{array}$ & $\begin{array}{l}0.019^{\star \star \star} \\
(0.001)\end{array}$ & \\
\hline Tenure sq & $\begin{array}{c}-0.000^{\star \star \star} \\
(0.000)\end{array}$ & $\begin{array}{l}-0.000 \\
(0.000)\end{array}$ & $\begin{array}{c}-0.000^{\star \star \star} \\
(0.000)\end{array}$ & \\
\hline Full time & $\begin{array}{l}0.300^{\star \star \star} \\
(0.031)\end{array}$ & $\begin{array}{c}1.581^{\star \star \star} \\
(0.068)\end{array}$ & $\begin{array}{c}0.397^{\star * *} \\
(0.020)\end{array}$ & \\
\hline Hours & $\begin{array}{l}0.004^{\star \star *} \\
(0.001)\end{array}$ & $\begin{array}{l}-0.056^{\star \star \star} \\
(0.001)\end{array}$ & $\begin{array}{l}0.002^{\star \star *} \\
(0.001)\end{array}$ & \\
\hline
\end{tabular}




\begin{tabular}{|c|c|c|c|c|}
\hline $\begin{array}{l}\text { Instruments } \\
\text { Work at home }\end{array}$ & & $\begin{array}{c}-0.271^{\star \star \star} \\
(0.038)\end{array}$ & & $\begin{array}{c}0.286 \star \star \star \\
(0.060)\end{array}$ \\
\hline \multicolumn{5}{|l|}{ No of Children } \\
\hline 1 & & & & $\begin{array}{c}0.020 \\
(0.025)\end{array}$ \\
\hline 2 & & & & $\begin{array}{c}0.035 \\
(0.029)\end{array}$ \\
\hline 3 & & & & $\begin{array}{c}0.020 \\
(0.042)\end{array}$ \\
\hline$>4$ & & & & $\begin{array}{c}-0.076^{\star \star} \\
(0.032)\end{array}$ \\
\hline Constant & $\begin{array}{c}5.932^{\star \star \star} \\
(0.036)\end{array}$ & $\begin{array}{c}1.467^{\star \star *} \\
(0.094)\end{array}$ & $\begin{array}{c}5.828^{\star \star *} \\
(0.034)\end{array}$ & $\begin{array}{c}-0.485^{\star \star \star} \\
(0.068)\end{array}$ \\
\hline $\begin{array}{l}\mathrm{N} \\
\text { Wald test } \\
\mathrm{H}_{0}: \rho=0\end{array}$ & $\begin{array}{c}15659 \\
x^{2}(1)=0.41 \\
p=0.52\end{array}$ & 31612 & $\begin{array}{c}10519 \\
x^{2}(1)=0.54 \\
p=0.46\end{array}$ & 32646 \\
\hline
\end{tabular}

Notes: Robust standard errors in parentheses; ${ }^{* * *} p<0.01,{ }^{* *} p<0.05,{ }^{*} p<0.1$. All returns are measured relative to a "Secondary" degree. The remaining regression output is available from the authors upon request.

\begin{tabular}{|c|c|c|c|c|}
\hline \multirow[t]{3}{*}{ Table A4 } & $\begin{array}{l}\text { ML estim } \\
\text { s in Gree }\end{array}$ & $\begin{array}{l}\text { tes of } \operatorname{Re} \\
e, 2002-2 \\
\end{array}$ & $\begin{array}{l}\text { Irns to Ac } \\
3 \text {, LFS }\end{array}$ & lemic \\
\hline & \multicolumn{2}{|c|}{ Males } & \multicolumn{2}{|c|}{ Females } \\
\hline & $\begin{array}{c}\text { (1) } \\
\text { Log(wage) }\end{array}$ & $\begin{array}{c}(2) \\
\text { Selection } \\
\text { (Employee } \\
\text { vs. Self- } \\
\text { employ) }\end{array}$ & $\begin{array}{c}\text { (3) } \\
\text { Log(wage) }\end{array}$ & $\begin{array}{c}(4) \\
\text { Selection } \\
\text { (Employee } \\
\text { vs. } \\
\text { Inactive) }\end{array}$ \\
\hline AEI & & & & \\
\hline Polytechnics & $\begin{array}{c}0.262^{\star \star \star} \\
(0.017)\end{array}$ & $\begin{array}{c}-0.331^{\star \star \star} \\
(0.048)\end{array}$ & $\begin{array}{c}0.351^{\star \star \star} \\
(0.026)\end{array}$ & $\begin{array}{c}0.840^{\star \star \star} \\
(0.093)\end{array}$ \\
\hline Computer Science & $\begin{array}{c}0.423^{\star \star *} \\
(0.047)\end{array}$ & $\begin{array}{c}0.266 \\
(0.231)\end{array}$ & $\begin{array}{c}0.367^{\star \star \star} \\
(0.066)\end{array}$ & $\begin{array}{c}0.348 \\
(0.258)\end{array}$ \\
\hline Agricultural Science & $\begin{array}{c}0.152^{\star \star \star} \\
(0.030)\end{array}$ & $\begin{array}{c}0.354^{\star \star \star} \\
(0.103)\end{array}$ & $\begin{array}{c}0.239 * \star * \\
(0.039)\end{array}$ & $\begin{array}{c}1.124^{\star \star \star} \\
(0.172)\end{array}$ \\
\hline Physics \& Maths & $\begin{array}{c}0.180 \star \star \star \\
(0.016)\end{array}$ & $\begin{array}{c}0.044 \\
(0.070)\end{array}$ & $\begin{array}{c}0.262^{\star \star \star} \\
(0.022)\end{array}$ & $\begin{array}{c}0.925^{\star \star \star} \\
(0.083)\end{array}$ \\
\hline Medicine & $\begin{array}{c}0.371^{\star \star *} \\
(0.024)\end{array}$ & $\begin{array}{c}-0.611^{\star \star *} \\
(0.065)\end{array}$ & $\begin{array}{c}0.435^{\star \star \star} \\
(0.027)\end{array}$ & $\begin{array}{c}0.810^{\star \star \star} \\
(0.096)\end{array}$ \\
\hline Law & $\begin{array}{c}0.288^{\star * *} \\
(0.046)\end{array}$ & $\begin{array}{c}-0.748^{\star * *} \\
(0.088)\end{array}$ & $\begin{array}{c}0.294^{\star * \star} \\
(0.032)\end{array}$ & $\begin{array}{c}0.702^{\star \star \star} \\
(0.089)\end{array}$ \\
\hline
\end{tabular}




\begin{tabular}{|c|c|c|c|c|}
\hline Economics \& Business & $\begin{array}{c}0.195^{\star \star *} \\
(0.014)\end{array}$ & $\begin{array}{c}0.060 \\
(0.043)\end{array}$ & $\begin{array}{c}0.184^{\star \star *} \\
(0.013)\end{array}$ & $\begin{array}{c}0.677^{\star \star \star} \\
(0.043)\end{array}$ \\
\hline Social Sciences & $\begin{array}{c}0.219 * \star \star \\
(0.039)\end{array}$ & $\begin{array}{l}0.356^{*} \\
(0.194)\end{array}$ & $\begin{array}{c}0.248^{\star \star \star} \\
(0.043)\end{array}$ & $\begin{array}{c}0.507^{\star \star \star} \\
(0.128)\end{array}$ \\
\hline Humanities & $\begin{array}{c}0.106^{\star * \star} \\
(0.020)\end{array}$ & $\begin{array}{c}0.067 \\
(0.105)\end{array}$ & $\begin{array}{c}0.227^{\star \star \star} \\
(0.015)\end{array}$ & $\begin{array}{c}0.833^{\star \star *} \\
(0.044)\end{array}$ \\
\hline Physical Education & $\begin{array}{c}0.112^{\star \star \star} \\
(0.023)\end{array}$ & $\begin{array}{l}0.205^{\star} \\
(0.118)\end{array}$ & $\begin{array}{c}0.186^{\star \star \star} \\
(0.035)\end{array}$ & $\begin{array}{c}1.051^{\star \star *} \\
(0.130)\end{array}$ \\
\hline Education & $\begin{array}{c}0.161^{\star \star \star} \\
(0.016)\end{array}$ & $\begin{array}{c}0.720^{\star \star \star} \\
(0.119)\end{array}$ & $\begin{array}{c}0.239^{\star \star \star} \\
(0.017)\end{array}$ & $\begin{array}{c}1.227^{\star \star \star} \\
(0.050)\end{array}$ \\
\hline TEI & & & & \\
\hline Polytechnics & $\begin{array}{c}0.146^{\star \star \star} \\
(0.015)\end{array}$ & $\begin{array}{c}0.159 \star \star \star \\
(0.059)\end{array}$ & $\begin{array}{c}0.157^{\star * *} \\
(0.031)\end{array}$ & $\begin{array}{c}0.722^{\star \star *} \\
(0.109)\end{array}$ \\
\hline Agricultural Science & $\begin{array}{l}0.067^{*} \\
(0.040)\end{array}$ & $\begin{array}{l}-0.179 \\
(0.156)\end{array}$ & $\begin{array}{l}0.118^{\star \star} \\
(0.056)\end{array}$ & $\begin{array}{c}0.612^{\star \star \star} \\
(0.177)\end{array}$ \\
\hline Food Technology & $\begin{array}{c}0.117 \\
(0.080)\end{array}$ & $\begin{array}{c}0.255 \\
(0.355)\end{array}$ & $\begin{array}{c}0.040 \\
(0.073)\end{array}$ & $\begin{array}{c}0.709^{\star \star \star} \\
(0.235)\end{array}$ \\
\hline Librarianship & NA & $\begin{array}{c}-6.561^{\star \star \star} \\
(0.161)\end{array}$ & $\begin{array}{c}0.099 \\
(0.085)\end{array}$ & $\begin{array}{c}0.985^{\star \star \star} \\
(0.348)\end{array}$ \\
\hline Medical-related & $\begin{array}{l}0.091^{\star \star} \\
(0.038)\end{array}$ & $\begin{array}{l}-0.039 \\
(0.129)\end{array}$ & $\begin{array}{c}0.164^{\star \star \star} \\
(0.017)\end{array}$ & $\begin{array}{c}1.041^{\star \star \star} \\
(0.059)\end{array}$ \\
\hline Applied Arts & $\begin{array}{c}0.134^{\star \star \star} \\
(0.052)\end{array}$ & $\begin{array}{c}0.165 \\
(0.284)\end{array}$ & $\begin{array}{c}0.195^{\star \star \star} \\
(0.074)\end{array}$ & $\begin{array}{c}0.256 \\
(0.239)\end{array}$ \\
\hline Constant & $\begin{array}{c}5.991^{\star * *} \\
(0.045)\end{array}$ & $\begin{array}{c}1.574^{\star \star \star} \\
(0.123)\end{array}$ & $\begin{array}{c}5.832^{\star * \star} \\
(0.044)\end{array}$ & $\begin{array}{c}-0.518^{\star * \star} \\
(0.088)\end{array}$ \\
\hline $\begin{array}{l}\text { Observations } \\
\text { Wald test } \\
\mathrm{H}_{0}: \rho=0\end{array}$ & $\begin{array}{c}10379 \\
x^{2}(1)=3.58 \\
p=0.058\end{array}$ & 19065 & $\begin{array}{c}7502 \\
x^{2}(1)=0.01 \\
p=0.91\end{array}$ & 18020 \\
\hline
\end{tabular}

\section{Appendix 2: Constructing a proxy for ability bias}

In constructing a suitable proxy for the differential abilities of university graduates within fields of study, we were constrained by the fact that only one wave (2002) contained information on the year in which the respondents left the tertiary education system. Based on this information, a variable that calculated the number of years of university study was constructed. From this it was then possible to compute the average number of years studied per academic discipline, since it is well-known that some 
degrees (e.g. Medical and Polytechnics) require more time for graduation than others. A minimum and a maximum time bound for each field was also defined as one standard deviation (-) and (+) the mean year, respectively, as shown in Table A5. Finally, three new dummy variables were added to the dataset, defined as follows:

(i) 1 if individuals' time of university study is less than the minimum bound by subject, 0 otherwise. This is believed to proxy for those individuals who dropped out of their studies (as we have now kept those respondents with incomplete studies in the analysis), and corresponds to $6.47 \%$ of the sample of graduates.

(ii) 1 if individuals' time of university study is between the minimum and maximum threshold, 0 otherwise. This category should act as surrogate for those people who experienced normal university tenure, and occupies the bulk of the sample of graduates (83.39\%).

(iii) 1 if individuals' time of university study exceeds the maximum bound, 0 otherwise. This group, which comprises $9.86 \%$ of the sample, should refer to students who, for various reasons (partly lack of motivation or lower ability), extended their university life.

As can be observed from Table A6, it is found that, compared to those who experienced normal university tenure, only individuals of the first group (i) suffer from statistically significant lower wages (7-8\%). The lack of significance of category (iii) may be possibly explained by the fact that many individuals of this type decide to extend their studies due to concurrent employment in the labour market in various jobs, which offers useful work experience. It is also important to notice that the estimates of Table A6 indicate that despite the inclusion in the regression of the above indicators of ability, the estimated returns to education remain largely unaffected. 
Table A5 Average Number of Years of Study by Academic Discipline in Greece, 2002, LFS

\begin{tabular}{|c|c|c|c|c|}
\hline Field & $\begin{array}{c}\text { Average no } \\
\text { years }\end{array}$ & s.d & Min bound & Upper bound \\
\hline \multicolumn{5}{|l|}{ AEI } \\
\hline Polytechnics & 6.38 & 2.48 & 3.90 & 8.76 \\
\hline \multirow{2}{*}{$\begin{array}{l}\text { Computer Science } \\
\text { Agricultural } \\
\text { Science }\end{array}$} & 5.51 & 1.7 & 3.81 & 7.21 \\
\hline & 5.99 & 2.31 & 3.68 & 8.3 \\
\hline Physics \& Maths & 5.9 & 2.48 & 3.42 & 8.38 \\
\hline Medicine & 7.36 & 2.58 & 4.77 & 9.94 \\
\hline Law & 5.83 & 1.92 & 3.91 & 7.74 \\
\hline $\begin{array}{l}\text { Economics \& } \\
\text { Business }\end{array}$ & 5.28 & 2.25 & 3.03 & 7.53 \\
\hline Social Sciences & 5.93 & 2.39 & 3.54 & 8.32 \\
\hline Humanities & 5.53 & 2.53 & 3 & 8.06 \\
\hline Physical Education & 5.43 & 2.31 & 3.12 & 7.73 \\
\hline Education & 4.16 & 2.36 & 1.8 & 6.52 \\
\hline \multicolumn{5}{|l|}{ TEI } \\
\hline Polytechnics & 4.71 & 2.11 & 2.6 & 6.81 \\
\hline $\begin{array}{l}\text { Agricultural } \\
\text { Science }\end{array}$ & 4.82 & 2.49 & 2.33 & 7.3 \\
\hline Food Technology & 4.77 & 1.38 & 3.39 & 6.16 \\
\hline Librarianship & 5.33 & 2.35 & 2.98 & 7.68 \\
\hline Medical-related & 4.52 & 2.03 & 2.48 & 6.55 \\
\hline Applied Arts & 5.3 & 2.59 & 2.7 & 7.9 \\
\hline
\end{tabular}

Notes: The min bound is calculated by subtracting one s.d. from the average number of years per field, while the max bound is obtained by adding one s.d.

\begin{tabular}{|c|c|c|c|c|}
\hline & $\begin{array}{c}\text { (1) } \\
\text { Males (no } \\
\text { ability proxy) }\end{array}$ & $\begin{array}{c}\text { (2) } \\
\text { Males (with } \\
\text { ability proxy) } \\
\end{array}$ & $\begin{array}{c}\text { (3) } \\
\text { Females (no } \\
\text { ability proxy) } \\
\end{array}$ & $\begin{array}{c}(4) \\
\text { Females } \\
\text { (with ability } \\
\text { proxy) } \\
\end{array}$ \\
\hline \multicolumn{5}{|l|}{ AEI } \\
\hline Polytechnics & $\begin{array}{c}-0.183^{\star \star *} \\
(0.040)\end{array}$ & $\begin{array}{c}-0.186^{\star \star *} \\
(0.040)\end{array}$ & $\begin{array}{c}-0.143^{\star \star \star} \\
(0.055)\end{array}$ & $\begin{array}{c}-0.155^{\star \star \star} \\
(0.055)\end{array}$ \\
\hline Computer Science & $\begin{array}{l}-0.006 \\
(0.092)\end{array}$ & $\begin{array}{l}-0.013 \\
(0.092)\end{array}$ & $\begin{array}{l}-0.086 \\
(0.103)\end{array}$ & $\begin{array}{l}-0.069 \\
(0.099)\end{array}$ \\
\hline Agricultural Science & $\begin{array}{c}-0.288^{\star * *} \\
(0.048)\end{array}$ & $\begin{array}{c}-0.290^{\star \star \star} \\
(0.048)\end{array}$ & $\begin{array}{c}-0.218^{\star * *} \\
(0.066)\end{array}$ & $\begin{array}{c}-0.229 * \star \star \\
(0.065)\end{array}$ \\
\hline Physics \& Maths & $\begin{array}{c}-0.208^{\star * *} \\
(0.039)\end{array}$ & $\begin{array}{c}-0.207^{\star \star *} \\
(0.039)\end{array}$ & $\begin{array}{c}-0.195^{\star \star \star} \\
(0.045)\end{array}$ & $\begin{array}{c}-0.206^{\star \star \star} \\
(0.044)\end{array}$ \\
\hline
\end{tabular}




\begin{tabular}{|c|c|c|c|c|}
\hline Law & $\begin{array}{l}-0.149^{\star} \\
(0.080)\end{array}$ & $\begin{array}{l}-0.154^{\star} \\
(0.080)\end{array}$ & $\begin{array}{l}-0.118^{\star \star} \\
(0.056)\end{array}$ & $\begin{array}{l}-0.129 \star \star \\
(0.055)\end{array}$ \\
\hline Economics \& Business & $\begin{array}{c}-0.188^{\star * *} \\
(0.038)\end{array}$ & $\begin{array}{c}-0.186^{\star \star \star} \\
(0.038)\end{array}$ & $\begin{array}{c}-0.228^{\star \star \star} \\
(0.039)\end{array}$ & $\begin{array}{c}-0.231^{\star \star \star} \\
(0.039)\end{array}$ \\
\hline Social Sciences & $\begin{array}{c}-0.194^{\star \star *} \\
(0.065)\end{array}$ & $\begin{array}{c}-0.195^{\star \star \star} \\
(0.065)\end{array}$ & $\begin{array}{l}-0.147^{\star *} \\
(0.074)\end{array}$ & $\begin{array}{l}-0.154^{\star *} \\
(0.075)\end{array}$ \\
\hline Humanities & $\begin{array}{c}-0.327^{\star \star *} \\
(0.042)\end{array}$ & $\begin{array}{c}-0.327^{\star \star \star} \\
(0.042)\end{array}$ & $\begin{array}{c}-0.214^{\star \star *} \\
(0.040)\end{array}$ & $\begin{array}{c}-0.222^{\star \star \star} \\
(0.040)\end{array}$ \\
\hline Physical Education & $\begin{array}{c}-0.291^{\star \star \star} \\
(0.045)\end{array}$ & $\begin{array}{c}-0.289^{\star \star \star} \\
(0.045)\end{array}$ & $\begin{array}{c}-0.181^{\star \star \star} \\
(0.059)\end{array}$ & $\begin{array}{c}-0.187^{\star \star \star} \\
(0.059)\end{array}$ \\
\hline Education & $\begin{array}{c}-0.242^{\star \star \star} \\
(0.040)\end{array}$ & $\begin{array}{c}-0.243^{\star \star \star} \\
(0.040)\end{array}$ & $\begin{array}{c}-0.220^{\star * *} \\
(0.040)\end{array}$ & $\begin{array}{c}-0.230 \star \star \star \\
(0.040)\end{array}$ \\
\hline TEI & & & & \\
\hline Polytechnics & $\begin{array}{c}-0.278^{\star \star *} \\
(0.038)\end{array}$ & $\begin{array}{c}-0.274^{\star \star \star} \\
(0.038)\end{array}$ & $\begin{array}{c}-0.231^{\star * *} \\
(0.054)\end{array}$ & $\begin{array}{c}-0.237^{\star \star \star} \\
(0.053)\end{array}$ \\
\hline Agricultural Science & $\begin{array}{c}-0.335^{\star \star \star} \\
(0.066)\end{array}$ & $\begin{array}{c}-0.330 * * \star \\
(0.065)\end{array}$ & $\begin{array}{c}-0.281^{\star \star \star} \\
(0.086)\end{array}$ & $\begin{array}{c}-0.286^{\star \star \star} \\
(0.085)\end{array}$ \\
\hline Food Technology & $\begin{array}{l}-0.181^{*} \\
(0.096)\end{array}$ & $\begin{array}{l}-0.174^{\star} \\
(0.093)\end{array}$ & $\begin{array}{c}-0.355^{\star \star \star} \\
(0.095)\end{array}$ & $\begin{array}{c}-0.367^{\star \star \star} \\
(0.095)\end{array}$ \\
\hline Librarianship & $\begin{array}{c}0.000 \\
(0.000)\end{array}$ & $\begin{array}{c}0.000 \\
(0.000)\end{array}$ & $\begin{array}{c}-0.373^{\star \star \star} \\
(0.138)\end{array}$ & $\begin{array}{c}-0.387^{\star \star \star} \\
(0.139)\end{array}$ \\
\hline Medical-related & $\begin{array}{c}-0.359 * * \star \\
(0.069)\end{array}$ & $\begin{array}{c}-0.358^{\star \star \star} \\
(0.070)\end{array}$ & $\begin{array}{c}-0.273^{\star \star \star} \\
(0.041)\end{array}$ & $\begin{array}{c}-0.278^{\star \star \star} \\
(0.040)\end{array}$ \\
\hline Applied Arts & $\begin{array}{c}-0.285^{\star \star \star} \\
(0.083)\end{array}$ & $\begin{array}{c}-0.289^{* \star *} \\
(0.082)\end{array}$ & $\begin{array}{l}-0.242 \\
(0.148)\end{array}$ & $\begin{array}{l}-0.258^{*} \\
(0.148)\end{array}$ \\
\hline Ability Indicators & & & & \\
\hline Below min time & & $\begin{array}{l}-0.076^{\star} \\
(0.041)\end{array}$ & & $\begin{array}{c}-0.074^{\star \star \star} \\
(0.027)\end{array}$ \\
\hline Above max time & & $\begin{array}{c}0.027 \\
(0.026)\end{array}$ & & $\begin{array}{c}0.011 \\
(0.027)\end{array}$ \\
\hline Constant & $\begin{array}{l}6.318^{\star * *} \\
(0.113)\end{array}$ & $\begin{array}{l}6.327^{\star \star \star} \\
(0.114)\end{array}$ & $\begin{array}{l}6.187^{\star * *} \\
(0.084)\end{array}$ & $\begin{array}{c}6.196^{\star \star *} \\
(0.084)\end{array}$ \\
\hline $\mathrm{N}$ & 1655 & 1655 & 1845 & 1845 \\
\hline $\mathrm{R}^{2}$ & 0.289 & 0.292 & 0.354 & 0.356 \\
\hline
\end{tabular}




\section{Endnotes}

${ }^{1}$ The University System includes the Universities, the Polytechnics, the Higher Fine Arts Institute and the Hellenic Open University. There are 20 universities in Greece located in various towns. There are also 14 Technological Education Institutes. The main distinction between AEI and TEI universities are that TEI courses are of shorter duration relative to those offered by AEI, are more practically oriented and the entry requirements are in general lower.

${ }^{2}$ More recent figures from the OECD (2008) place the percentage close to $18 \%$.

${ }^{3}$ Katsanevas (2002) calculates that Greece has by far the largest ratio of doctors or lawyers per head in the EU. In the year 2000 one lawyer corresponded to every 338 residents, compared to the average EU ratio of 1:850, while the ratio of doctors per residents in the whole country stands at 1/185 (in Athens it is 1/150), compared to 1/350-400 in the EU (Fyntanidoy, 2001).

${ }^{4}$ These negative prospects have been confirmed by Katsanevas (2002), who studied "the balance of supply and demand of professions.” In this research the conventional fields of Medicine, Law, and Education were classified as having very negative prospects for the future. At the same time the fields of IT, telecommunications and of new technologies, in general, presented very promising opportunities. Both the European Commission (1996) and the OECD (2005) have also argued that Greek universities are merely producing 'degree holders' who, in the face of a shrinking public sector, have a higher probability of experiencing unemployment/underemployment.

5 This question becomes even more important in the face of recent evidence that the level of pay of Greek graduates is quite responsive to a tentative rise in unemployment at the aggregate level (Livanos, 2008[b]),

${ }^{6}$ The spring quarter is used (following Eurostat guidelines) as it is the one from which the annual employment figures are produced in all EU countries.

7 Earnings are calculated as the net monthly wage that the respondents receive from their main employment inclusive of any extraneous payments (such as Christmas and Easter bonus, annual leave remuneration and other irregular bonuses). Specifically, the level of individual income is measured at the midpoint of the respective income band specified by the Greek LFS. The consistency of the wage information has been corroborated with comparison of the LFS data with other major EU datasets that include Greece, such as the EU-SILC and the European Survey on Working Conditions (ESWC). Finally, it is also important to notice that using nominal rather than real wage terms should not affect the relative ranking of the various academic disciplines, as only the constant term would change in the estimation procedure.

${ }^{8}$ Buchinsky (2001) shows that there may be considerable differences between the semiparametric estimates that he proposes and those obtained by a traditional parametric probit model in the selection equation.

${ }^{9}$ This matches closely with the 0.26 coefficient reported by Machin and McNally (2007) for Greek men.

${ }^{10}$ A formal Heckman-type econometric procedure has been employed that confirms that the estimated returns between the public and private sectors are not subject to selectivity bias. However, identification of the model is achieved only on the basis of non-linearities in the functional forms of the equations. For this reason, the results of the selection model are not presented in the paper, though they are available from the authors upon request.

${ }^{11}$ The effect of the remaining variables that are included in the wage equations conforms to the familiar patterns that have been reported in the literature (see Table A1), namely upward-sloping age-earnings profiles that are relatively steeper for males; marriage yielding an wage premium over other marital states; full-time workers (particularly women) enjoying higher remuneration relative to part-timers; and wage rates varying substantially among regions, with residents of the capital of Athens and of surrounding areas enjoying higher returns. The cohort dummies also indicate that younger cohorts in Greece are facing an earnings disadvantage relative to older cohorts, which appears to be more pronounced for females.

${ }^{12}$ The rate of self-employment is much lower for the female employed population, close to 8-9\%, which is why the analysis has focussed on the male sample in the text. Nevertheless, it is also confirmed that the female wage returns do not suffer from selectivity bias (available from the authors upon request).

13 These results are available from the authors upon request.

${ }^{14}$ Individuals born prior to 1950 are neglected, given the limited number of observations that result in small cell sizes by field of study.

${ }^{15}$ In the past, almost one-third of the Greek student population studied abroad; in 197560000 students were registered in Greek institutions and 30000 abroad. Even today nearly 60000 Greek students continue to study abroad (compared to 370000 who are registered in Greek universities i.e. approximately 14\% of the total university graduate population). 